\title{
Comprehensive investigation of a dye-decolorizing peroxidase and a manganese peroxidase from Irpex lacteus F17, a lignin-degrading basidiomycete
}

\author{
Zihong Duan ${ }^{1,2 \dagger}$, Rui Shen ${ }^{1,2+}$, Binjie Liu ${ }^{1,2}$, Mengwei Yao ${ }^{1,2}$ and Rong Jia ${ }^{1,2^{*}}$
}

\begin{abstract}
Irpex lacteus F17 is well-known for its ability to degrade recalcitrant aromatic pollutants, which mainly results from the action of the manganese peroxidase (MnP) that it is able to produce. Recently, the genome sequencing and annotation of this strain provided comprehensive picture of the ligninolytic peroxidase gene family. In addition to revealing the presence of $13 \mathrm{MnPs}$, genes for five dye-decolorizing peroxidases (DyPs) were also discovered in the I. lacteus F17 genome, which are unrelated to the fungal class II peroxidases. In the present study, amino acid sequences of five DyPs and $13 \mathrm{MnPs}$, representing two different families of heme peroxidases, were analyzed. Of these, two enzymes, a DyP (II-DyP4) and a MnP (II-MnP6) were expressed respectively in Escherichia coli, and were characterized by comparing their molecular models, substrate specificities, and catalytic features. The results showed that II-DyP4 possessed a higher catalytic efficiency for some representative substrates, and a stronger decolorizing ability to a wide range of synthetic dyes in acidic conditions. Based on electrochemical measurements, II-DyP4 was found to have a high redox potential of $27 \mathrm{mV}$ at $\mathrm{pH} 3.5$, which was superior to that of II-MnP6 $(-75 \mathrm{mV})$, thereby contributing to its ability to oxidize high redox potential substrates, such as veratryl alcohol and polymeric dye Poly R-478. The results highlighted the potential of II-DyP4 for use in industrial and environmental applications.
\end{abstract}

Keywords: Irpex lacteus F17, White-rot fungus, Dye-decolorizing peroxidase, Manganese peroxidase, Redox potential, Biotechnological applications

\section{Introduction}

Lignocellulose is a structural component of the plant cell wall, mainly comprising cellulose, hemicellulose, and lignin. It is the largest renewable resource in nature and the most promising feedstock for the production of many valuable substances, such as biofuels, chemicals, and materials, from plant sources (Balat 2011). Both cellulose and hemicellulose are carbohydrates, whereas lignin is a highly irregular and insoluble polymer comprising phenylpropanoid units, chemically bonded by mostly

\footnotetext{
*Correspondence: ahdxjiarong@126.com

†Zihong Duan and Rui Shen contributed equally to this work

${ }^{2}$ Anhui Key Laboratory of Modern Biomanufacturing, Anhui University,

Hefei 230601, People's Republic of China

Full list of author information is available at the end of the article
}

ether linkage and carbon-carbon bonds, which are both physically stable and chemically inert (Park et al. 2018). In woody plants, lignin accounts for $20-35 \%$ in woody biomass and forms lignin-carbohydrate complexes with cellulose and hemicellulose, resulting in xylem that is extremely hard; however, these complexes are difficult to separate and degrade, thus hindering the conversion and utilization of lignocelluloses (Cheng et al. 2012).

Wood-decaying fungi, one of several groups of lignocellulose decomposers in nature, have an important role in the terrestrial carbon cycle (Kellner et al. 2014). They are common inhabitants of forest litter and fallen trees and have typically been classified as white-rot fungi and brown-rot fungi, according to their ability to biodegrade lignin. Brown-rot fungi are capable of degrading carbohydrates, leaving polyaromatic lignin intact because of 
their lack of ligninolytic enzymes, whereas white-rot fungi have a ligninolytic system, which can degrade lignin as well as cellulose and hemicelluloses (Morgenstern et al. 2008; Ruiz-Dueñas et al. 2013). Therefore, whiterot fungi have received considerable research because of their extracellular lignolytic enzymes, with a focus on secreted fungal class II peroxidases (PODs), such as lignin peroxidase (LiP; EC 1.11.1.14), manganese peroxidase (MnP; EC 1.11.1.13), and versatile peroxidase (VP; EC 1.11.1.16), as well as other classes of enzyme, such as copper-dependent laccases (Fernández-Fueyo et al. 2014). Thus, two types of fungi can be distinguished by the presence or absence of PODs, which can affect the mode of wood decay adopted by white-rot or brownrot fungi. However, recently published work, based on the genomic data from 33 species of fungi, suggests that a more nuanced categorization of wood decay modes between white-rot and brown-rot fungi is necessary, because numerous other classes of enzyme were found to be involved in lignin degradation in addition to PODs (Riley et al. 2014). For example, genes encoding PODs are absent in the genomes of Botryobasidium botryosum and Jaapia argillacea genomes, although both species show modes of lignin degradation that are similar to those of some white-rot fungi. Moreover, the secondary metabolites reducing polyketide synthases (R-PKSs) are abundant in white-rot fungi but reduced in brown-rot fungi. In addition, the dye-decolorizing peroxidases (DyPs), a second new heme peroxidase superfamily, were identified in fungi that have been shown to degrade model lignin compounds, and were also widespread in white-rot fungi, such as Auricularia delicate and Trametes versicolor, whereas brown-rot fungi lack DyPs (Floudas et al. 2012, 2015).

DyPs are a newly discovered family of heme peroxidases that are unrelated to well-known peroxidases, such as fungal class II PODs, in terms of their amino acid sequence, tertiary structure, and catalytic residues (Colpa et al. 2014). They have a unique protein structure, as well as a distinct amino acid sequence, with a substrate preference for anthraquinone dyes and high peroxidase activity toward a variety of organic compounds (Sugano 2009). The ability of DyPs to oxidize lignin-related compound and nonphenolic lignin model dimers and their low catalytic efficiency on $\mathrm{Mn}^{2+}$ and veratryl alcohol have also been reported (Kinne et al. 2011; Colpa et al. 2014; Fernández-Fueyo et al. 2015; Linde et al. 2015; Loncar et al. 2016). All DyPs contain an iron protoporphyrin IX (heme cofactor) as a prosthetic group and the GXXDG motif in their primary sequence as a part of the heme-binding region (Colpa et al. 2014). They also share a conserved spatial structure and a unique ferredoxin-like fold containing $\alpha$-helices and antiparallel $\beta$-sheets (Linde et al. 2015). Nevertheless, the physiological function of these enzymes is unclear, although they exhibit the biotechnological potential (Colpa et al. 2014; van Bloois et al. 2010).

Irpex lacteus F17 is an indigenous white-rot basidiomycete isolated by our laboratory that efficiently decolorizes and degrades different synthetic dyes, some of which are recalcitrant for their structural diversity (Zhao et al. 2015; Yang et al. 2016). Initially, this strain was named Schizophyllum sp. F17 based on the morphological characteristics of its fruiting body (Cheng et al. 2007) and recognized as I. lacteus F17 after identifying the internal transcribed spacer in its nucleotide sequence (GenBank: JQ403610.3.2) and analyzing its phylogenetic tree (Chen et al. 2015). Recently, genome sequencing of I. lacteus F17 revealed that the genome encodes 14 Class II PODs and five DyPs. The 14 PODs enzymes include one LiP and 13 putative MnPs. Phylogenetic analysis based on 18S rRNA sequences showed that I. lacteus F17 was closely related to Ceriporiopsis subvermispora and Phanerochaete chrysosporium (Yao et al. 2017). Interestingly, the genome of C. subvermispora also encodes $13 \mathrm{MnPs}$, whereas it has no genes encoding DyPs, similar to $P$. chrysosporium (Fernández-Fueyo et al. 2012; Floudas et al. 2012).

Research has focused mainly on MnPs from I. lacteus, probably because of their abundance in the genome of this species (Yao et al. 2017). MnPs from I. lacteus are important in the degradation of polycyclic aromatic hydrocarbons and are able to efficiently decolorize different groups of dye (Novotný et al. 2001; Kasinath et al. 2003; Baborová et al. 2006). Recent research indicated that two MnPs from I. lacteus CD2 were able to degrade veratryl alcohol, a nonphenolic lignin compound (Qin et al. 2017). The ability of MnP purified from $I$. lacteus F17 to degrade synthetic dyes has also been shown (Chen et al. 2015). However, little is known about the catalytic properties of DyP from I. lacteus. To the best of our knowledge, only a wild DyP from I. lacteus grown in liquid medium, has been isolated and characterized (Salvachúa et al. 2013). Thus, we selected a DyP gene (No. 8293, GenBank: MG 209114) from the I. lacteus F17 genome and expressed it in Escherichia coli, and compared it with a MnP gene (No. 6398, GenBank: MG 209112) from the same genome. Any similarities and differences between the two enzymes in terms of their sequence homologies, molecular structures, biochemi$\mathrm{cal}$ and spectroscopic properties, as well as their ability to decolorize different types of dye, were investigated. The results of this study will further reveal the catalytic characteristics of DyPs from I. lacteus F17 to provide a better understanding of the lignin degradation potential of this strain. 


\section{Materials and methods}

\section{Regents and expression vectors}

Dithiothreitol (DTT), glutathione (GSSG), phenylmethanesulfonyl fluoride (PMSF), and isopropyl $\beta$-D-thiogalactopyranoside (IPTG) were from SigmaAldrich (St. Louis, MO, USA). Reactive Blue 19 (RBlue 19), reactive black 5 (RBlack 5), veratryl alcohol (VA), 2,6-dimethoxyphenol (DMP), ethylene diamine tetraacetic acid (EDTA), and 2,2-azino-bis(3-ethylbenzothiazoline-6-sulfonic acid) (ABTS) were purchased from Aladdin industrial corporation (Shanghai, China).

The E. coli expression vector $\mathrm{pET} 28 \mathrm{a}(+)$ and the $E$. coli expression host Rosetta (DE3) were purchased from Invitrogen (Carlsbad, CA, USA) and TransGen Biotech (Beijing, China), respectively.

All restriction enzymes and DNA polymerases were purchased from TaKaRa (Ostu, Japan). Unless otherwise specified, all other reagents used were from Macklin (Shanghai, China) and were of analytical grade.

\section{Strain and genome}

The strain of I. lacteus F17 was cultured on potato dextrose agar (PDA) medium (200 $\mathrm{g} \mathrm{L}^{-1}$ of potato extract, $20 \mathrm{~g} \mathrm{~L}^{-1}$ of glucose, and $20 \mathrm{~g} \mathrm{~L}^{-1}$ of agar) for 5 days at $28{ }^{\circ} \mathrm{C}$ and then preserved at $4{ }^{\circ} \mathrm{C}$.

I. lacteus F17 was deposited at the China Center for Type Culture Collection (CCTCC) under the accession number of CCTCC AF 2014020. The whole-genome shotgun project has been submitted to GenBank under the accession number MQVO00000000 (http://www. ncbi.nlm.nih.gov).

\section{DyP and MnP screening of the I. lacteus F17 genome}

The DyP and MnP coding genes in I. lacteus F17 were screened as follows. First, the annotated genome was automatically searched in the NCBI database; second, multiple alignments were performed using Clustal $\mathrm{X}$ to compare the deduced amino acid sequences with related peroxidases; finally, the presence of characteristic residues at the heme pocket and substrate oxidation sites were confirmed.

Five DyP genes and $13 \mathrm{MnP}$ genes were identified in the genome of $I$. lacteus F17. The cDNA sequences encoding the 18 mature proteins were submitted to GenBank: Il-DyP1 (MH120197), Il-DyP2 (MH120198), Il-DyP3 (MH120199), Il-DyP4 (MG209114), Il-DyP5 (MH120196), as well as Il-MnP1 (KC811382), Il-MnP2 (MH120200), Il-MnP3 (MH120201), Il-MnP4 (MH120202), IlMnP5 (MH120203), Il-MnP6 (MG209112), IlMnP7 (MH120204), Il-MnP8 (MH120205), Il-MnP9 (MH120206), Il-MnP10 (MH120207), Il-MnP11
(MH120208), and Il-MnP12 (MH120209), Il-MnP13 (MH120210).

Based on Protein Blast on NCBI, sequence identity analyses of five DyPs and $13 \mathrm{MnPs}$ in the I. lacteus F17 were performed. In addition, homology modeling was performed on the basis of the SWISS MODEL server to obtain the templates of crystal structure with the highest identity in the protein database. The templates were then applied to PyMOL to simulate the three-dimensional structure of the proteins and to superimpose the heme, important amino acids, and ions.

\section{Gene clone and expression vector construction}

Mycelia of I. lacteus F17 were cultured in compound potato dextrose agar (CPDA) liquid medium at $28{ }^{\circ} \mathrm{C}$ at $120 \mathrm{rpm}$ and harvested on the fourth day. Total RNA was extracted as reported by Koo et al. (1998). The total RNA was then reverse transcribed to cDNA.

Il-DyP4 primers DyPf and DyPr (Additional file 1: Table S1) were designed. The above cDNA of I. lacteus F17 was used as a template and polymerase chain reactions (PCR) were performed with Taq DNA polymerase. The PCR products were detected by gel electrophoresis in $0.8 \%$ agarose gels, stained using SuperRed/GelRed, and subsequently sequenced. Two primers were designed at the $5^{\prime}$ and $3^{\prime}$ ends of the $I l$-DyP4 gene with the following sequences: NcoI-DyPf and XhoI-DyPr, which contained the restriction sites $N c o I$ and XhoI (underlined). The resulting PCR product was gel-purified, digested with $\mathrm{NcoI}$ and XhoI, and cloned into the corresponding site of the $\mathrm{pET} 28 \mathrm{a}(+)$ vector to construct the recombinant plasmid pET28a-Il-DyP4. The plasmid was transformed into chemically competent E. coli Rosetta (DE3) cells and then confirmed by DNA sequencing. The gene clone and expression strain of $\mathrm{Il}-\mathrm{MnP6}$ were constructed using the same method (see Additional file 1: Table S1 for primers).

\section{II-DyP4 and II-MnP6 expression in E. coli}

A positive transformant harboring $\mathrm{pET} 28 \mathrm{a}-\mathrm{DyP} 4$ was isolated as a single colony for gene expression. The transformant was cultured overnight at $37^{\circ} \mathrm{C}$ in $5 \mathrm{~mL} \mathrm{LB}$ medium containing $50 \mu \mathrm{g} \mathrm{mL}{ }^{-1}$ kanamycin and $34 \mu \mathrm{g} \mathrm{mL}^{-1}$ chloramphenicol. The culture was then inoculated into fresh LB medium $400 \mathrm{~mL}$ containing kanamycin and chloramphenicol and grown at $37{ }^{\circ} \mathrm{C}$ and $200 \mathrm{rpm}$ to an $\mathrm{OD}_{600}$ of approximately 0.6. IPTG was then added to a final concentration of $0.5 \mathrm{mM}$ for induction for $4 \mathrm{~h}$, bacterial pellets were obtained by centrifugation at $4{ }^{\circ} \mathrm{C}$ at $12,000 \times g$ for $10 \mathrm{~min}$, and were resuspended in lysis buffer $(0.02 \mathrm{mM}$ PMSF, $50 \mathrm{mM}$ Tris- $\mathrm{HCl}$, and $\mathrm{pH}$ 7.5) in a quarter of the 
original culture volume. Bacteria were then lysed by sonication for $45 \mathrm{~min}$. The lysed cells were centrifuged at $4{ }^{\circ} \mathrm{C}$ at $12,000 \times g$ for $30 \mathrm{~min}$ to obtain precipitation.

The $\mathrm{Il}-\mathrm{MnP} 6$ protein was expressed according to the method of Chen et al. (2015).

\section{In vitro activation of II-DyP4 and II-MnP6}

Il-DyP4 was expressed in the form of inclusion bodies and was solubilized in $10 \mathrm{~mL} 50 \mathrm{mM}$ Tris- $\mathrm{HCl}(\mathrm{pH}$ 8.0) containing $8 \mathrm{M}$ urea, $1 \mathrm{mM}$ EDTA, for $3 \mathrm{~h}$ at $4{ }^{\circ} \mathrm{C}$ to complete solubilization of the $\mathrm{Il}$-DyP4 polypeptide. The refolding reaction system included $2 \mathrm{mM}$ EDTA, $20 \mu \mathrm{M}$ hemin, and $1 \mathrm{M}$ urea, and had a $\mathrm{pH}$ of 6.0.

To investigate the optimal activation conditions for $\mathrm{Il}$ DyP4 protein refolding, $0.2 \mathrm{~mL}$ protein $\left(1.2 \mathrm{mg} \mathrm{mL}^{-1}\right)$ was taken and optimized in 5-mL eppendorf tubes. Variable parameters include $\mathrm{pH}(1.0-8.0)$, EDTA $(0-8 \mathrm{mM})$, hemin $(0-60 \mu \mathrm{M})$, and urea $(0.1-2.5 \mathrm{M})$. Refolding was performed at $4{ }^{\circ} \mathrm{C}$ for $24 \mathrm{~h}$.

Larger-scale refolding assays were performed using the optimized conditions found in the small-scale experiments. The supernatant, including active $\mathrm{Il}$-DyP4, was dialyzed against $10 \mathrm{mM}$ sodium acetate $(\mathrm{pH} 6)$ for subsequent purification. The insoluble material was eliminated by centrifugation at $12,000 \times g$ for $30 \mathrm{~min}$.

The refolding results were evaluated by measuring the Il-DyP4 residual enzyme activity using ABTS as reducing substrate according to the enzyme activity assay. Similarly, recombinant $I l-\mathrm{MnP} 6$ was expressed in the form of inclusion bodies. In vitro refolding was performed according to the method of Wang et al. (2016).

\section{II-DyP4 and II-MnP6 activity assays}

Il-DyP4 activity was estimated spectrophotometrically by the oxidation of $1.25 \mathrm{mM}$ ABTS to its cation radical $\left(\varepsilon_{418}=36,000 \mathrm{M}^{-1} \mathrm{~cm}^{-1}\right)$ in $100 \mathrm{mM}$ sodium tartrate buffer at $\mathrm{pH} 3.5$ at $25^{\circ} \mathrm{C}$.

Il-MnP6 activity was determined using two substrates. The first was determined based on the oxidation of $\mathrm{Mn}^{2+}$ to $\mathrm{Mn}^{3+}$ at $25{ }^{\circ} \mathrm{C}$ and $240 \mathrm{~nm}\left(\varepsilon_{240}=6500 \mathrm{M}^{-1} \mathrm{~cm}^{-1}\right)$ at $\mathrm{pH} 4.5$ in $0.11 \mathrm{M}$ sodium lactate buffer (Salvachúa et al. 2013). The second was followed by the oxidation of $1.25 \mathrm{mM}$ DMP to its cation radical $\left(\varepsilon_{469}=27,500 \mathrm{M}^{-1} \mathrm{~cm}^{-1}\right)$ in $100 \mathrm{mM}$ sodium tartrate buffer containing $1 \mathrm{mM} \mathrm{MnSO}_{4}$, at $\mathrm{pH} 4$ at $55^{\circ} \mathrm{C}$.

In all cases, peroxidase activity assays were carried out in the presence of $0.1 \mathrm{mM} \mathrm{H}_{2} \mathrm{O}_{2}$ and were carried out in triplicate. Control treatments without $\mathrm{H}_{2} \mathrm{O}_{2}$ and/or without enzyme were also performed. One unit $(\mathrm{U})$ of peroxidase oxidized $1 \mu \mathrm{mol}$ of substrate/min, and units were calculated based upon $\mathrm{U} \mathrm{mg}^{-1}$ of protein per $\mathrm{mL}^{-1}$ of enzyme solution.

\section{Purification of DyP and MnP and mass characterization}

Refolded solutions containing recombinant $\mathrm{Il}$-DyP4 and $\mathrm{Il}$-MnP6 were purified using Ni-NTA affinity chromatography. Sodium dodecyl sulfate polyacrylamide gel electrophoresis (SDS-PAGE) was performed using a $12 \%$ Tris- $\mathrm{HCl}$ separation gel, and samples were then stained with Coomassie Brilliant Blue R-250.

Furthermore, purified proteins were identified by mass spectrometry. First, purified recombinant $\mathrm{Il}$ DyP4 and $I l-\mathrm{MnP} 6$ proteins were excised from the gel and digested with trypsin. Subsequently, the resulting peptide mixtures were analyzed by liquid chromatography-mass spectrometry (LC-MS) using a Proteome X-LTQ mass spectrometer (Thermo Fisher Scientific, Waltham, MA, USA). All obtained peptides were compared with the predicted amino acid sequence of $\mathrm{Il}$ DyP4 and $\mathrm{Il}$-MnP6.

\section{Effect of $\mathrm{pH}$ and temperature on DyP and MnP activity and stability}

The optimum $\mathrm{pH}$ for substrate oxidation activity of $\mathrm{Il}$ DyP4 and $\mathrm{Il}-\mathrm{MnP} 6$ was estimated at $25^{\circ} \mathrm{C}$ in $0.11 \mathrm{M}$ citrate-phosphate buffer ( $\mathrm{pH} 2.2-8.0)$ or Tris-HCl buffer ( $\mathrm{pH}$ 8.6-9.0). To evaluate the $\mathrm{pH}$ stability, the enzymes were incubated at $4{ }^{\circ} \mathrm{C}$ for $12 \mathrm{~h}$ at different $\mathrm{pH}(2.2-9.0)$.

The optimum temperature for $\mathrm{Il}$-DyP4 activity was measured from 0 to $60{ }^{\circ} \mathrm{C}$ in appropriate increments in $0.1 \mathrm{M}$ sodium tartrate buffer ( $\mathrm{pH} 3.5)$. The optimum temperature for $\mathrm{Il}-\mathrm{MnP} 6$ activity was measured from 0 to $85{ }^{\circ} \mathrm{C}$ in appropriate increments in $0.11 \mathrm{M}$ sodium lactate buffer ( $\mathrm{pH} 4.5)$. To evaluate the thermal stability of $\mathrm{Il}$-DyP4 and $\mathrm{Il}$-MnP6, the enzymes were incubated at temperatures ranging from 4 to $65{ }^{\circ} \mathrm{C}$ in appropriate increments for $12 \mathrm{~h}$.

The residual enzyme activities of $\mathrm{Il}$-DyP4 and $\mathrm{Il}$ MnP6 were determining using ABTS and $\mathrm{Mn}^{2+}$, respectively, as substrates.

\section{Substrate specificities}

Eight different substrates $\left[\mathrm{H}_{2} \mathrm{O}_{2}, \quad\right.$ ABTS $\left(\varepsilon_{418}=36,000 \mathrm{~cm}^{-1} \mathrm{M}^{-1}\right), \mathrm{Mn}^{2+}\left(\varepsilon_{240}=6500 \mathrm{~cm}^{-1} \mathrm{M}^{-1}\right)$, DMP $\quad\left(\varepsilon_{469}=27,500 \quad \mathrm{~cm}^{-1} \quad \mathrm{M}^{-1}\right), \quad$ guaiacol $\left(\varepsilon_{456}=12,100 \mathrm{~cm}^{-1} \mathrm{M}^{-1}\right)$, VA $\left(\varepsilon_{310}=9300 \mathrm{~cm}^{-1} \mathrm{M}^{-1}\right)$, RBlue19 $\quad\left(\varepsilon_{595}=10,000 \quad \mathrm{~cm}^{-1} \mathrm{M}^{-1}\right), \quad$ RBlack 5 $\left.\left(\varepsilon_{598}=30,000 \mathrm{~cm}^{-1} \mathrm{M}^{-1}\right)\right]$ were used to study the substrate specificities of $\mathrm{Il}$-DyP4 and $\mathrm{Il}-\mathrm{MnP} 6$ in $0.1 \mathrm{M}$ sodium tartrate. The reactions were initiated by the addition of $0.1 \mathrm{mM} \mathrm{H}_{2} \mathrm{O}_{2}$. In the $\mathrm{MnP}$ reaction system, $1 \mathrm{mM} \mathrm{Mn}^{2+}$ was added. The oxidation activity for these substrates was measured based on the molar absorbance of the corresponding reaction product at the specific wavelength. 
Steady-state kinetic constants of $\mathrm{Il}$-DyP4 or $\mathrm{Il}$-MnP6 were determined spectrophotometrically using a UVvisible spectrophotometer (Shanghai, China). First, the effect of $\mathrm{pH}$ and temperature on the activity for oxidation of eight different substrates by both enzymes were investigated, respectively, and then the optimal values were used to determine their kinetic constants $\left(K_{m}, k_{\text {cat }}\right.$ and $\left.k_{c a t} / K_{m}\right)$ by the hyperbolic, non-linear least squares method.

\section{$\mathrm{H}_{2} \mathrm{O}_{2}$ stability and the effects of compounds on enzyme activity}

The $\mathrm{H}_{2} \mathrm{O}_{2}$ stability of both enzymes was determined by incubating $25 \mathrm{nM}$ of enzyme for $30 \mathrm{~min}$ at $25{ }^{\circ} \mathrm{C}$ in the presence of increasing $\mathrm{H}_{2} \mathrm{O}_{2}$ enzyme concentrations $(0-10 \mathrm{mM})$. The residual activities were then monitored using the method for assaying enzyme activity.

Additionally, under the specified enzyme activity measurement conditions, $I l$-DyP4 used ABTS as a substrate, whereas $I l-\mathrm{MnP} 6$ used DMP as a substrate. Residual enzyme activity was determined in the presence and absence of three different concentrations $(0.1,1$, and $10 \mathrm{mM})$ of different cations $\left(\mathrm{Co}^{2+}, \mathrm{Ba}^{2+}, \mathrm{Cd}^{2+}, \mathrm{Mn}^{2+}\right.$, $\mathrm{Na}^{+}, \mathrm{Ca}^{2+}, \mathrm{Mg}^{2+}, \mathrm{Zn}^{2+}, \mathrm{Ni}^{2+}, \mathrm{Cu}^{2+}, \mathrm{Fe}^{2+}, \mathrm{Fe}^{2+}$, and $\left.\mathrm{Al}^{3+}\right)$, thiourea, EDTA, DTT, and $\beta$-mercaptoethanol. Enzymes were incubated with these compounds for $5 \mathrm{~min}$ before the activity measurement.

\section{Spectroscopic characterization of II-DyP4 and II-MnP6}

Far-UV CD spectra measurements were implemented with a MOS-500 CD spectrometer (Bio-Logic, Grenoble, France), with a 1-mm light path cell. The protein concentration was $0.1 \mathrm{mg} \mathrm{mL}^{-1}$ in $0.15 \mathrm{M}$ phosphate buffer at $\mathrm{pH}$ 6.5. The CD spectra were recorded using a $2-\mathrm{mm}$ bandwidth in the far-UV region (190-250 nm) at room temperature.

UV-Vis spectra were obtained in the 200-700 nm region at room temperature using a DU 730 UV spectrophotometer (Beckman Coulter, Brea, CA, USA); the $\mathrm{Il}$-DyP4 concentration was $0.58 \mathrm{mg} \mathrm{mL}^{-1}$ in $0.1 \mathrm{M}$ phosphate buffer at $\mathrm{pH} 6.0$ and that of $\mathrm{Il}-\mathrm{MnP} 6$ was $1.26 \mathrm{mg} \mathrm{mL}^{-1}$ in $0.1 \mathrm{M}$ sodium acetate buffer at $\mathrm{pH} 5.9$.

\section{II-DyP4 and II-MnP6 electrochemical experiments}

Cyclic voltammetry (CV) was used to determine the redox potential of $I l-\mathrm{DyP} 4$ and $I l-\mathrm{MnP} 6$. Pyrolytic graphite electrode (PGE), platinum wire, and $\mathrm{Ag} / \mathrm{AgCl}$ were used as the working electrode, the counter electrode, and reference electrode, respectively (Mendes et al. 2015). The first step the PGE surface was polished with $\mathrm{Al}_{2} \mathrm{O}_{3}$ on sandpaper (2000 mesh); secondly, the electrode was thoroughly ultrasonicated with water and ethanol for $5 \mathrm{~min}$ each; thirdly, $5 \mu \mathrm{g}$ protein was dropped onto the
PGE, and maintained at $4{ }^{\circ} \mathrm{C}$ for $20 \mathrm{~h}$ to allow the protein to fully adsorb to the electrode surface. Finally, the electrode was cleaned with distilled water, measured for a scan rate at $50 \mathrm{mV} \mathrm{s}^{-1}$, and the potential was then cycled between -1.0 and $+0.6 \mathrm{~V}$.

\section{Dye decolorization}

The decolorization ability of $\mathrm{Il}$-DyP4 or $\mathrm{Il}$-MnP6 towards five different classes of dye (anthraquinone dyes, azo dyes, phenazine dyes, triphenylmethane dyes, and aniline dyes) was measured using a spectrophotometer. Reaction mixtures contained $100 \mathrm{mM}$ sodium tartrate buffer $(\mathrm{pH}$ 3.5, 4.0 or 4.5), $25 \mathrm{nM}$ of purified enzyme and dyes (at a concentration of $25-200 \mu \mathrm{M})$; the concentration ratio of $\mathrm{H}_{2} \mathrm{O}_{2}$ /dye was $4: 1$. Besides, $1 \mathrm{mM} \mathrm{Mn}^{2+}$ was supplemented in the $\mathrm{Il}-\mathrm{MnP} 6$ reaction system. Reactions were subsequently performed for $30 \mathrm{~min}$ at $35{ }^{\circ} \mathrm{C}$, and were then examined for the level of decolorization by the two enzymes.

Decolorization assays of polymeric dye Poly R-478 were performed to reveal the ability of $\mathrm{Il}-\mathrm{DyP} 4$ or $\mathrm{Il}-\mathrm{MnP} 6$ to degrade lignin. The reaction mixture contained sodium tartrate buffer $(100 \mathrm{mM})$, Poly R-478 dye (0.01\%), and $\mathrm{Il}$ DyP4 $(100 \mathrm{nM})$ or $\mathrm{Il}$-MnP6 $(100 \mathrm{nM})$ in a total volume of $1 \mathrm{~mL}$ (MnP reaction system added $1 \mathrm{mM} \mathrm{Mn}^{2+}$ ). The reaction was initiated by the addition of $\mathrm{H}_{2} \mathrm{O}_{2}(0.2 \mathrm{mM})$ and the mixture was incubated at different $\mathrm{pH}$ conditions at $35{ }^{\circ} \mathrm{C}$ for $30 \mathrm{~min}$. Dye decolorization was measured using a spectrophotometer at $520 \mathrm{~nm}$, which is the maximum visible absorbance of Poly R-478. Control samples, without enzyme or $\mathrm{H}_{2} \mathrm{O}_{2}$, were done in parallel under identical conditions.

The decolorization percentage was calculated according to Eq. 1.

$$
\text { Decolorization(\%) }=\frac{A_{0}-A_{t}}{A_{0}} \times 100 \%
$$

where $A_{0}$ is the initial absorbance at $\lambda_{\max }(\mathrm{nm})$ and $A_{\mathrm{t}}$ refers to the absorbance at $\lambda_{\max }(\mathrm{nm})$ at reaction time $\mathrm{t}$. The data were the mean values of triplicate experiments.

\section{Results}

\section{DyP and MnP cDNAs analyses}

Amino acid sequence alignments of five DyPs ( $\mathrm{Il}$ DyP1-5: accession numbers MH120197, MH120198, MH120199, MG209114, and MH120196, respectively) from I. lacteus F17 displayed typical characteristic GXXDG conserved motifs (Additional file 1: Fig. S1). Some crucial role of the conserved amino acid residues were shown in colors, such as the proximal histidine residue as well as the distant aspartic acid and arginine residues. There was a $57-83 \%$ shared sequence 
identity among the five DyPs (Additional file 1: Table S2). Moreover, alignment analysis of conserved amino acid sites in 13 MnPs (Il-MnP1-13: KC811382, MH120200, MH120201, MH120202, MH120203, MG209112, MH120204, MH120205, MH120206, MH120207, MH120208, MH120209, and MH120210, respectively) from I. lacteus F17 was also performed (Additional file 1: Fig. S2). Likewise, some crucial role of the conserved amino acid residues was shown in colors, including $\mathrm{Mn}^{2+}$-binding and $\mathrm{Ca}^{2+}$-binding amino acid ligands etc. There was a $49-99 \%$ shared sequence identity among the 13 MnPs (Additional file 1: Table S3).

To understand the essential characteristics and biochemical properties of these two different types of enzyme, we tested DyPs and MnPs expression levels in I. lacteus $\mathrm{F} 17$ by culturing this organism in CPDA liquid shake cultures $\left(28^{\circ} \mathrm{C}\right)$. Genes encoding $\mathrm{Il}$-DyP4 and Il-MnP6 were found to be the predominant expressed genes. Therefore, Il-DyP4 (MG209114) and Il-MnP6 (MG209112) were selected for further research.

According to the ExPASy (Gasteiger et al. 2003) server prediction online, $\mathrm{Il}$-DyP4 contained 502 amino acids, with a molecular weight of $54.5 \mathrm{kDa}$ and a theoretical $\mathrm{pI}$ of 5.06. The signal peptide of $\mathrm{Il}$-DyP4 was confirmed to contain 52 amino acids (Salvachúa et al. 2013). In addition, Il-DyP4 showed 58\% identity with BadDyP (GenBank: BAA77283.1) from Bjerkandera adusta, 42\% identity with Pleurotus ostreatus DyP (GenBank: CAK55151.1), 40\% identity with T. versicolor DyP (GenBank: EIW57847.1), and $<33 \%$ identity with DyPs from bacteria, such as E. coli (PDB 5GT2_A), Shewanella oneidensis (PDB 2HAG_A), and Bacteroides thetaiotaomicron (PDB 2GVK_A). According to the ExPASy server, Il-MnP6 contained 359 amino acids, with a molecular weight of $38.2 \mathrm{kDa}$ and a theoretical pI of 4.94. Using SignalP 4.1, the signal peptide of $\mathrm{Il}-\mathrm{MnP} 6$ was predicted to be 23 amino acids long. In addition, $\mathrm{Il}-\mathrm{MnP} 6$ showed 73\% identity with MnP3 (GenBank: CAD92855.1) from Phlebia radiata, $72 \%$ identity with MnP (GenBank: CAG33918.4) from T. versicolor, and 55\% identity with MnP (GenBank: AAB30859.1) from P. chrysosporium. Moreover, Il-MnP6 contained eight cysteines, and formed four disulfide bonds, and its amino acid sequence revealed an $89 \%$ identity with previously reported $\mathrm{Il}$ MnP1 (GenBank:AGO86670.2) from I. lacteus F17, indicating that it is a short-type MnP (Chen et al. 2015). As such, the other $11 \mathrm{MnPs}$ in I. lacteus F17 genome also belonged to the short MnP subfamily, based on the analyses of their amino acid sequences.

To analyze the structural properties of the two enzymes, molecular models of the deduced mature proteins were built (Additional file 1: Fig. S3). For $\mathrm{Il}$ DyP4, the crystal structure of B. adusta DyP (PDB 3afv) (sequence identity 62.19\%) was used as a template. For Il-MnP6, the crystal structure of Pleurotus eryngii VP (PDB 2boq) was used as a template (sequence identity $70.61 \%)$. In addition, the presence of the amino acids residues mentioned above was confirmed in the two structural models (Additional file 1: Fig. S3).

\section{Expression and in vitro activation of II-DyP4 and II-MnP6}

The cDNA sequences encoding $I l-\mathrm{DyP} 4$ and $I l-\mathrm{MnP} 6$ were amplified by PCR and inserted into the expression vector $\mathrm{pET} 28 \mathrm{a}(+)$. The resulting recombinant constructs were then transformed into E. coli Rosetta (DE3) cells for heterologous expression.

The optimum enzyme activity achieved for $\mathrm{Il}$-DyP4 was $10.8 \mathrm{U} \mathrm{mg}^{-1}$, using the following optimal refolding conditions: $1 \mathrm{mM}$ EDTA, $5 \mu \mathrm{M}$ hemin, $0.75 \mathrm{M}$ urea in $50 \mathrm{mM}$ phosphate (pH 6) (Fig. 1a-d).

The optimum enzyme activity of $\mathrm{Il}-\mathrm{MnP} 6$ was $2 \mathrm{U} \mathrm{mg}^{-1}$, using the following optimal refolding conditions: $1.5 \mathrm{M}$ urea, $150 \mathrm{mM} \mathrm{CaCl}_{2}, 25 \mu \mathrm{M}$ hemin, $10 \%$ glycerol, $0.5 \mathrm{mM} \mathrm{GSSG}, 0.05 \mathrm{mM} \mathrm{MnSO}_{4}, 20 \mathrm{mM} \mathrm{KCl}$ in $50 \mathrm{mM}$ Tris- $\mathrm{HCl}$ (pH 8.5).

\section{Purification of II-DyP4 and II-MnP6 and mass characterization}

Two recombinant proteins with six His-tags at the $\mathrm{C}$ terminus were purified using Ni-NTA affinity chromatography, and exhibited a single band on SDS-PAGE (Additional file 1: Fig. S4). Purified $\mathrm{Il}$-DyP4 had a molecular weight of $54.0 \mathrm{kDa}$, close to the $54.5 \mathrm{kDa}$ predicted. The final recovery, which was obtained from the total activity, was approximately $85 \%$ (Table 1 ). The specific activity of purified $\mathrm{Il}$-DyP4 was $140 \mathrm{U} \mathrm{mg}^{-1}$. Purified $\mathrm{Il}$ MnP6 had a molecular weight of $44.6 \mathrm{kDa}$, close to the $38.2 \mathrm{kDa}$ predicted (Additional file 1: Fig. S4). The final recovery of $I l-\mathrm{MnP} 6$ was almost $60 \%$ (Table 1 ). The specific activity of purified $\mathrm{Il}$-MnP6 was $23.8 \mathrm{U} \mathrm{mg}^{-1}$.

The purified $\mathrm{Il}$-DyP4 was analyzed by mass spectrometry. These peptides accurately matched the deduced amino acid sequence of $I l$-DyP4 (see Additional file 1: Table S4). The first fragment (MGSAGNDSLPFENIQGDILVGMKK) was the N-terminus amino acid sequence, which has $100 \%$ identity with the native I. lacteus DyP (Salvachúa et al. 2013).

Similarly, the purified $I l-\mathrm{MnP} 6$ was also analyzed by mass spectrometry. These peptides accurately matched the deduced amino acid sequence of $\mathrm{Il}$-MnP6 (see Additional file 1: Table S5). Thus, these data confirmed the successful expression of $\mathrm{Il}$-DyP4 and $\mathrm{Il}-\mathrm{MnP} 6$ in $\mathrm{E}$. coli Rosetta (DE3). 

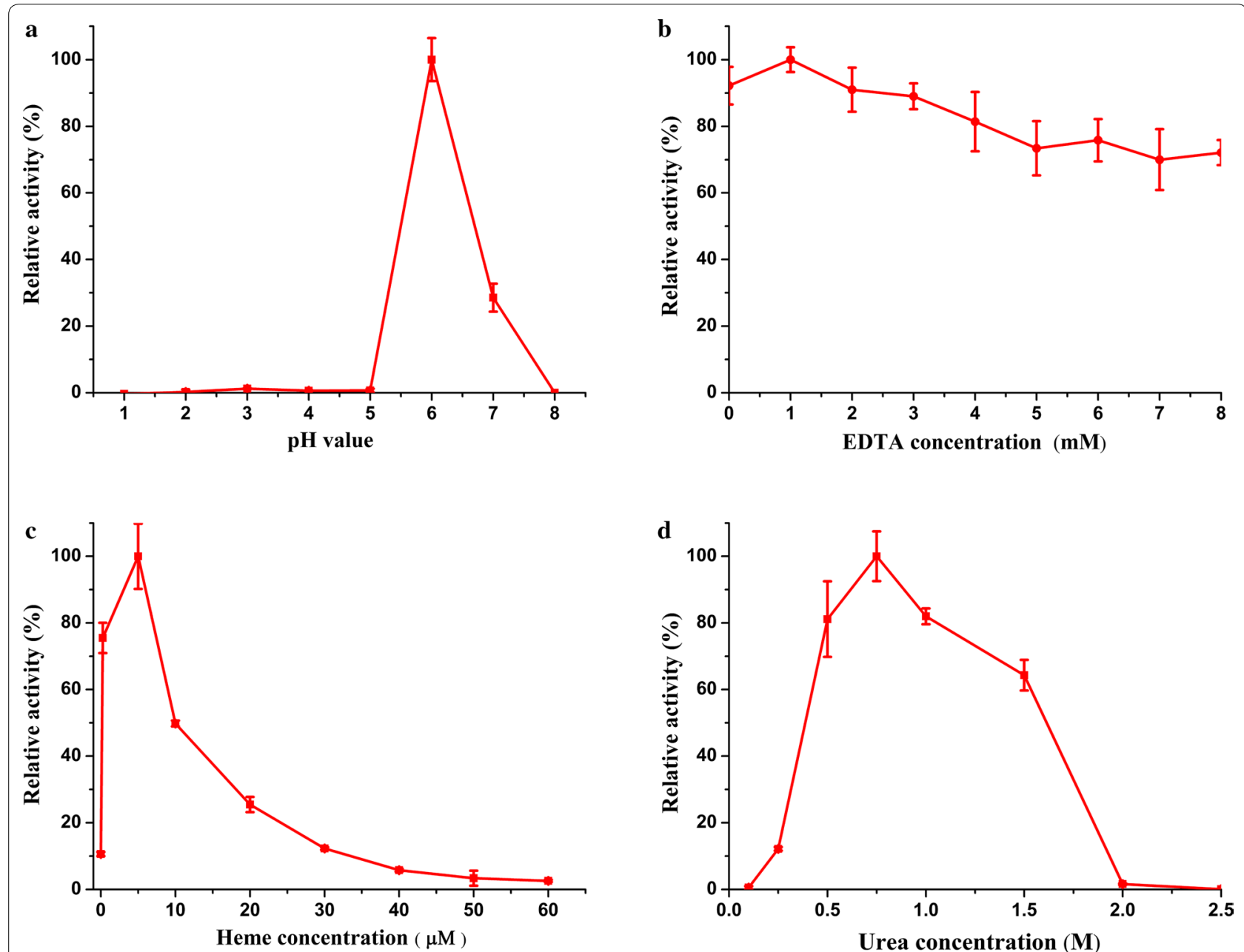

Fig. 1 The effect of several parameters on the refolding of recombinant II-DyP4. a pH, b EDTA concentration, $\mathbf{c}$ hemin concentration, and $\mathbf{d}$ urea concentration were systematically examined. All reactions were performed with $1.2 \mathrm{mg} \mathrm{mL}^{-1}$ protein in $50 \mathrm{mM}$ phosphate buffer. The reactions took place in the dark for $24 \mathrm{~h}$ at $4^{\circ} \mathrm{C}$. The residual activity of II-DyP4 was measured according to enzyme activity assay. Deviation values are standard deviations based on triplicate determinations

Table 1 Isolation and purification of II-DyP4 and II-MnP6 from inclusion bodies

\begin{tabular}{|c|c|c|c|c|c|c|}
\hline & Sample & $\begin{array}{l}\text { Protein concentration } \\
\left(\mathrm{mg} \mathrm{mL}^{-1}\right)\end{array}$ & Protein (mg) & $\begin{array}{l}\text { Specific activity } \\
\left(\mathrm{U} \mathrm{mg}^{-1}\right)\end{array}$ & Total activity (U) & Yield (\%) \\
\hline \multirow[t]{3}{*}{ DyP } & Inclusion body & 8.78 & 87.8 & & & \\
\hline & Dialyzed & 0.24 & 28.2 & 10.8 & 305 & 100 \\
\hline & $\mathrm{Ni}-\mathrm{NTA}$ & 0.0093 & 1.87 & 140 & 261 & 86 \\
\hline \multirow[t]{3}{*}{$\mathrm{MnP}$} & Inclusion body & 4.45 & 22.2 & & & \\
\hline & Dialyzed & 0.23 & 8.1 & 2 & 16.2 & 100 \\
\hline & Ni-NTA & 0.0082 & 0.41 & 23.8 & 9.8 & 60 \\
\hline
\end{tabular}

Effects of $\mathrm{pH}$ and temperature on the activity and stability of II-DyP4 and II-MnP6

The optimal $\mathrm{pH}$ of $\mathrm{Il}$-DyP4 for ABTS oxidation was 3.5 (Fig. 2a). During incubation of $\mathrm{Il}$-DyP4 in different $\mathrm{pH}$ buffers for $12 \mathrm{~h}$, the enzyme retained more than $80 \%$ of its enzymatic activity at $\mathrm{pH} 4-7$ and was most stable at pH 5.5 (Fig. 2b). Unlike $I l$-DyP4, the optimum $\mathrm{pH}$ of $\mathrm{Il}$ MnP6 showed double peaks (4.5 and 7.0), and used $\mathrm{Mn}^{2+}$ as a substrate. $\mathrm{Il}$-MnP6 also retained $>75 \%$ of its enzymatic activity at a wider range of $\mathrm{pH}$ (3.5-7.5), indicating 


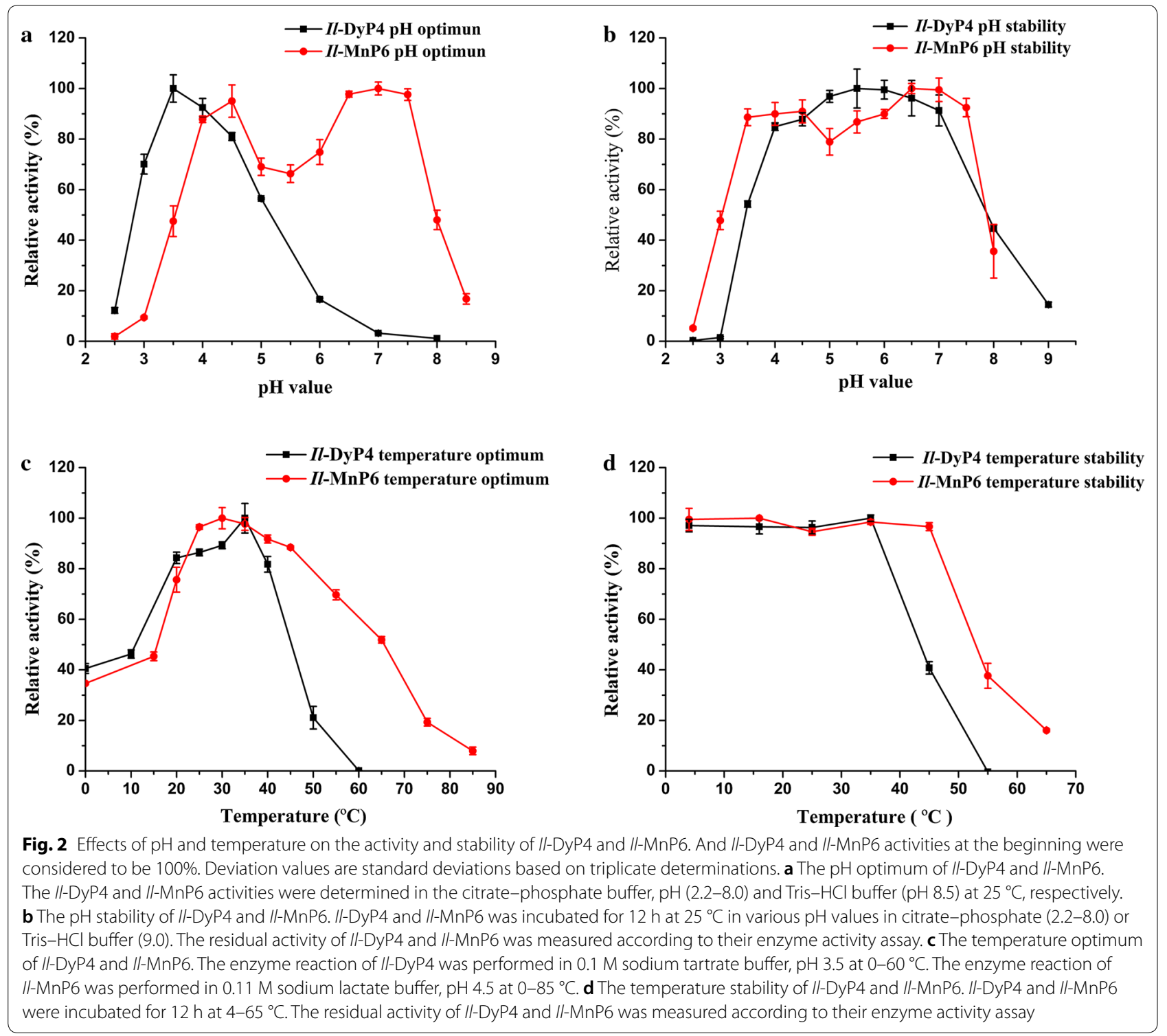

that the $\mathrm{pH}$ stability of $\mathrm{Il}-\mathrm{MnP} 6$ was superior to that of Il-DyP4.

Il-DyP4 exhibited the highest enzymatic activity at $35{ }^{\circ} \mathrm{C}$ and retained $90 \%$ of its enzymatic activity after incubation at temperatures below $35^{\circ} \mathrm{C}$ for $12 \mathrm{~h}$ (Fig. 2c, d). $\mathrm{Il}$-MnP6 showed maximal enzymatic activity at $30^{\circ} \mathrm{C}$ and retained $>90 \%$ of its enzymatic activity below $45^{\circ} \mathrm{C}$ for $12 \mathrm{~h}$.

\section{Substrate specificities of II-DyP4 and II-MnP6}

Significant differences were recorded in the substrate specificities of $\mathrm{Il}$-DyP4 and $\mathrm{Il}$-MnP6 on eight representative substrates (Table 2). For heme-containing peroxidases, $\mathrm{H}_{2} \mathrm{O}_{2}$ was used as an electron-accepting substrate to oxidize a variety of compounds. The results showed that the catalytic efficiency of $\mathrm{Il}$-DyP4 in the reduction of $\mathrm{H}_{2} \mathrm{O}_{2}$ was an order of magnitude higher than that of Il-MnP6. For ABTS oxidation, the catalytic efficiency $\left(k_{\text {cat }} / K_{m}\right)$ of $\mathrm{Il}$-DyP4 was up to $1.3 \times 10^{8} \mathrm{~s}^{-1} \mathrm{M}^{-1}$, two orders of magnitude higher than that of $I l-\mathrm{MnP} 6$. For $\mathrm{Mn}^{2+}$ oxidation, which is often used as a substrate for $\mathrm{MnP}$, the catalytic efficiency $\left(k_{\text {cat }} / K_{m}\right)$ of $\mathrm{Il}$-DyP4 was $3.0 \times 10^{5} \mathrm{~s}^{-1} \mathrm{M}^{-1}$, which was an order of magnitude lower than that of $I l-M n P 6$. Phenolic substrates, such as DMP and guaiacol, which were commonly used as universal substrates for heme peroxidase, displayed similar catalytic efficiency for $I l-\mathrm{DyP} 4$ and $I l-\mathrm{MnP} 6$. VA, a nonphenolic compound, was also assayed, revealing the 
Table 2 Kinetic parameters- $K_{m}(\mu \mathrm{M}), k_{c a t}\left(s^{-1}\right)$, and $k_{c a t} / K_{m}\left(s^{-1} \mathrm{M}^{-1}\right)$ of II-DyP4 and II-MnP6 for substrates oxidation obtained based on the optimal $\mathrm{pH}$ and temperature $\left({ }^{\circ} \mathrm{C}\right)$

\begin{tabular}{|c|c|c|c|c|c|c|c|c|}
\hline \multirow[b]{3}{*}{$\mathrm{H}_{2} \mathrm{O}_{2}^{\mathrm{a}}$} & \multicolumn{4}{|c|}{ II-DyP4 } & \multicolumn{4}{|c|}{ II-MnP6 } \\
\hline & \multirow{2}{*}{$\frac{\mathbf{p H}}{3.5}$} & \multirow{2}{*}{$\begin{array}{l}\text { Temperature } \\
35\end{array}$} & \multicolumn{2}{|c|}{ Kinetic constants } & \multirow{2}{*}{$\begin{array}{l}\mathrm{pH} \\
4.5\end{array}$} & \multirow{2}{*}{$\begin{array}{l}\text { Temperature } \\
30\end{array}$} & \multicolumn{2}{|c|}{ Kinetic constants } \\
\hline & & & $K_{m}$ & $163 \pm 20.8$ & & & $K_{m}$ & $194 \pm 18$ \\
\hline & & & $k_{\text {cat }}$ & $(1.2 \pm 0.08) \times 10^{4}$ & & & $k_{\text {cat }}$ & $879 \pm 48$ \\
\hline & & & $k_{c a t} / K_{m}$ & $(7.6 \pm 0.5) \times 10^{7}$ & & & $k_{c a t} / K_{m}$ & $(4.5 \pm 0.3) \times 10^{6}$ \\
\hline \multirow[t]{3}{*}{ ABTS } & 3.5 & 35 & $K_{m}$ & $62 \pm 11$ & 3.5 & 45 & $K_{m}$ & $83 \pm 6.5$ \\
\hline & & & $k_{\text {cat }}$ & $8356 \pm 747$ & & & $k_{\text {cat }}$ & $245 \pm 7$ \\
\hline & & & $k_{\text {cat }} / K_{m}$ & $(1.3 \pm 0.1) \times 10^{8}$ & & & $k_{\text {cat }} / K_{m}$ & $(3.0 \pm 0.09) \times 10^{6}$ \\
\hline \multirow[t]{3}{*}{$\mathrm{Mn}^{2+}$} & 4.5 & 35 & $K_{m}$ & $2687 \pm 463$ & 4.5 & 30 & $K_{m}$ & $129 \pm 8$ \\
\hline & & & $k_{\text {cat }}$ & $806 \pm 94$ & & & $k_{\text {cat }}$ & $369 \pm 6.1$ \\
\hline & & & $k_{\text {cat }} / K_{m}$ & $(3.0 \pm 0.4) \times 10^{5}$ & & & $k_{\text {cat }} / K_{m}$ & $(2.9 \pm 0.3) \times 10^{6}$ \\
\hline \multirow[t]{3}{*}{ DMP } & 4 & 35 & $K_{m}$ & $58 \pm 3$ & 4.5 & 55 & $K_{m}$ & $53 \pm 8.6$ \\
\hline & & & $k_{\text {cat }}$ & $4896 \pm 131$ & & & $k_{c a t}$ & $989 \pm 100$ \\
\hline & & & $k_{\text {cat }} / K_{m}$ & $(8.4 \pm 0.2) \times 10^{7}$ & & & $k_{\text {cat }} / K_{m}$ & $(1.9 \pm 0.2) \times 10^{7}$ \\
\hline \multirow[t]{3}{*}{ Guaiacol } & 4 & 45 & $K_{m}$ & $24 \pm 7.5$ & 4 & 45 & $K_{m}$ & $2.6 \pm 0.6$ \\
\hline & & & $k_{\text {cat }}$ & $413 \pm 34$ & & & $k_{c a t}$ & $184 \pm 7$ \\
\hline & & & $k_{\text {cat }} / K_{m}$ & $(1.7 \pm 0.1) \times 10^{7}$ & & & $k_{\text {cat }} / K_{m}$ & $(7.1 \pm 0.3) \times 10^{7}$ \\
\hline \multirow[t]{3}{*}{ VA } & 3.5 & 45 & $K_{m}$ & $(2.1 \pm 0.98) \times 10^{4}$ & $-{ }^{b}$ & - & $K_{m}$ & $-{ }^{c}$ \\
\hline & & & $k_{\text {cat }}$ & $108 \pm 47$ & & & $k_{\text {cat }}$ & - \\
\hline & & & $k_{\text {cat }} / K_{m}$ & $(5.2 \pm 2.3) \times 10^{3}$ & & & $k_{c a t} / K_{m}$ & - \\
\hline \multirow[t]{3}{*}{ RBlue 19} & 4.5 & 35 & $K_{m}$ & $133 \pm 34$ & 3 & 35 & $K_{m}$ & $81 \pm 39.5$ \\
\hline & & & $k_{c a t}$ & $5345 \pm 921$ & & & $k_{c a t}$ & $7.3 \pm 2.6$ \\
\hline & & & $k_{\text {cat }} / K_{m}$ & $(4.0 \pm 0.7) \times 10^{7}$ & & & $k_{\text {cat }} / K_{m}$ & $(9.0 \pm 3.2) \times 10^{4}$ \\
\hline \multirow[t]{3}{*}{ RBlack 5} & 4 & 35 & $K_{m}$ & $159 \pm 61$ & 3 & 35 & $K_{m}$ & $4.4 \pm 0.7$ \\
\hline & & & $k_{c a t}$ & $267 \pm 96$ & & & $k_{c a t}$ & $0.06 \pm 0.003$ \\
\hline & & & $k_{\text {cat }} / K_{m}$ & $(1.7 \pm 0.6) \times 10^{6}$ & & & $k_{c a t} / K_{m}$ & $(1.5 \pm 0.07) \times 10^{4}$ \\
\hline
\end{tabular}

Means and 95\% confidence limits

a Activities were measured with $1.25 \mathrm{mM} \mathrm{ABTS}$ and $1 \mathrm{mM} \mathrm{Mn}^{2+}$ by II-DyP4 and II-MnP6, respectively

b Not detected

c Experimental condition: $[\mathrm{VA}]=1 \mathrm{mM},[\mathrm{MnP}]=25 \mathrm{nM},\left[\mathrm{H}_{2} \mathrm{O}_{2}\right]=0.1 \mathrm{mM},\left[\mathrm{MnSO}_{4}\right]=1.0 \mathrm{mM}$, $[$ Tartrate buffer $]=100 \mathrm{mM}, \mathrm{pH}=3.5$, temperature $=45^{\circ} \mathrm{C}$, reaction time $=60 \mathrm{~min}$

catalytic efficiency of $\mathrm{Il}$-DyP4 to be $5.2 \times 10^{3} \mathrm{~s}^{-1} \mathrm{M}^{-1}$, although no activity was detected for $\mathrm{Il}-\mathrm{MnP} 6$ in $0.1 \mathrm{M}$ sodium tartrate, $\mathrm{pH}$ 3.5. For two dyes tested, the catalytic efficiency of $I l$-DyP4 oxidizing anthraquinone dye RBlue 19 was $4.0 \times 10^{7} \mathrm{~s}^{-1} \mathrm{M}^{-1}$, which was three orders of magnitude higher than that of $I l-M n P 6$. The catalytic efficiency of $\mathrm{Il}$-DyP4 oxidizing azo dyes RBlack 5 was $1.7 \times 10^{6} \mathrm{~s}^{-1} \mathrm{M}^{-1}$, which was two orders of magnitude higher that of $I l-\mathrm{MnP} 6$.

\section{Effects of $\mathrm{H}_{2} \mathrm{O}_{2}$ and chemicals on II-DyP4 and II-MnP6 activity}

In general, fungal heme-containing peroxidases depend on $\mathrm{H}_{2} \mathrm{O}_{2}$ to start the catalytic cycle of the reaction, although the enzymes are prone to inactivation in the presence of excess $\mathrm{H}_{2} \mathrm{O}_{2}$. The $\mathrm{H}_{2} \mathrm{O}_{2}$ stability of $\mathrm{Il}$ DyP4 and $\mathrm{Il}-\mathrm{MnP6}$ showed that the enzyme activity of
Il-DyP4 was reduced by $60 \%$ as the $\mathrm{H}_{2} \mathrm{O}_{2}$ concentration increased from 0.1 to $4 \mathrm{mM}$, whereas the enzyme activity of $\mathrm{Il}-\mathrm{MnP} 6$ was reduced by $10 \%$. However, when the $\mathrm{H}_{2} \mathrm{O}_{2}$ concentration was increased from 4 to $10 \mathrm{mM}$, the enzyme activity of $I l$-DyP4 was reduced by only $10 \%$, whereas $80 \%$ of the enzymatic activity of $\mathrm{Il}-\mathrm{MnP} 6$ was lost rapidly. Therefore, $\mathrm{Il}$-DyP4 was less resistant to low $\mathrm{H}_{2} \mathrm{O}_{2}$ concentrations, and more resistant to high $\mathrm{H}_{2} \mathrm{O}_{2}$ concentrations, and vice versa for $\mathrm{Il}$-MnP6.

The effects of three concentrations of several metal ions and other compounds on $\mathrm{Il}$-DyP4 and $\mathrm{Il}-\mathrm{MnP} 6$ were also assayed (Table 3). For $\mathrm{Mn}^{2+}, \mathrm{Na}^{+}, \mathrm{Mg}^{2+}, \mathrm{Zn}^{2+}, \mathrm{Ni}^{2+}$, $\mathrm{Cu}^{2+}$, and $\mathrm{Al}^{3+}$, no loss of enzyme activity was observed for $\mathrm{Il}$-DyP4 and $\mathrm{Il}$-MnP6 within the tested concentrations. When the concentrations of $\mathrm{Co}^{2+}$ and $\mathrm{Ca}^{2+}$ were increased to $10 \mathrm{mM}, \mathrm{Il}$-DyP4 was significantly inhibited, whereas no significant effect was observed on $\mathrm{Il}$-MnP6. Both $\mathrm{Fe}^{3+}$ and $\mathrm{Fe}^{2+}$ significantly inhibited the activity 
Table 3 Effects of different chemicals on the activity of II-DyP4 and II-MnP6

\begin{tabular}{|c|c|c|c|c|c|c|}
\hline \multirow[t]{3}{*}{ Chemicals } & \multicolumn{3}{|l|}{ II-DyP4 ${ }^{\mathrm{a}}$} & \multicolumn{3}{|l|}{ II-MnP6 ${ }^{\mathbf{b}}$} \\
\hline & \multicolumn{3}{|c|}{ Relative enzyme activity (\%) } & \multicolumn{3}{|c|}{ Relative enzyme activity (\%) } \\
\hline & $0.1 \mathrm{mM}$ & $1 \mathrm{mM}$ & $10 \mathrm{mM}$ & $0.1 \mathrm{mM}$ & $1 \mathrm{mM}$ & $10 \mathrm{mM}$ \\
\hline $\mathrm{Co}^{2+}$ & 97 & 76 & 21 & 107 & 107 & 111 \\
\hline $\mathrm{Ba}^{2+}$ & 101 & 103 & 88 & 106 & 95 & 115 \\
\hline $\mathrm{Cd}^{2+}$ & 100 & 103 & 87 & 103 & 98 & 51 \\
\hline $\mathrm{Mn}^{2+}$ & 101 & 100 & 102 & 67 & 100 & 106 \\
\hline $\mathrm{Na}^{+}$ & 99 & 93 & 96 & 103 & 96 & 98 \\
\hline $\mathrm{Ca}^{2+}$ & 87 & 79 & 47 & 94 & 97 & 90 \\
\hline $\mathrm{Mg}^{2+}$ & 102 & 100 & 102 & 93 & 105 & 108 \\
\hline $\mathrm{Zn}^{2+}$ & 88 & 86 & 72 & 91 & 93 & 85 \\
\hline $\mathrm{Ni}^{2+}$ & 100 & 106 & 102 & 98 & 97 & 92 \\
\hline $\mathrm{Cu}^{2+}$ & 104 & 109 & 98 & 96 & 98 & 50 \\
\hline $\mathrm{Fe}^{2+}$ & 8 & 9 & 1 & 19 & 0 & 0 \\
\hline $\mathrm{Fe}^{3+}$ & 104 & 13 & 2 & 100 & 37 & 0 \\
\hline $\mathrm{Al}^{3+}$ & 107 & 107 & 69 & 100 & 91 & 22 \\
\hline Thiourea & 99 & 93 & 33 & 95 & 82 & 19 \\
\hline EDTA & 99 & 107 & 87 & 93 & 8 & 4 \\
\hline DTT & 99 & 1 & 0 & 25 & 0 & 0 \\
\hline$\beta$-Mercaptoethanol & 92 & 45 & 0 & 15 & 0 & 0 \\
\hline
\end{tabular}

a ABTS oxidation by the II-DyP4

b DMP oxidation by the II-MnP6

of both enzymes, except at low concentrations of $\mathrm{Fe}^{3+}$ $(0.1 \mathrm{mM})$.

DTT, thiourea, and $\beta$-mercaptoethanol had little effect on $\mathrm{Il}$-DyP4 activity at lower concentrations $(0.1 \mathrm{mM})$, whereas $\mathrm{Il}-\mathrm{MnP} 6$ activity was completely or partially inhibited when using $0.1 \mathrm{mM}$ and $1 \mathrm{mM}$ of these compounds. There was no change in $I l$-DyP4 activity at the three EDTA concentrations tested, whereas Il-MnP6 activity declined rapidly.

\section{Spectroscopic characterization of II-DyP4 and II-MnP6}

Circular dichroism (CD) spectra measurement in the farUV region is often used to observe the secondary structures of proteins. The far-UV CD spectra of $I l-D y P 4$ and Il-MnP6 exhibited two negative ellipticity bands at 208 and $222 \mathrm{~nm}$, respectively (Additional file 1: Fig. S5), indicating $\alpha$-helical structure characteristics, but with significant differences in content. The $\alpha$-helix and $\beta$-sheet contents of $\mathrm{Il}-\mathrm{DyP} 4$ and $\mathrm{Il}-\mathrm{MnP} 6$ were calculated using the K2D program. The results showed that the $\alpha$-helical content of $I l$-DyP4 ( $\geq 9 \%)$ was lower than that of $I l-\mathrm{MnP} 6$ $(\geq 17 \%)$, whereas the $\beta$-sheet content of $I l$-DyP4 ( $\geq 43 \%)$ was higher than that of $I l-\mathrm{MnP6}(\geq 31 \%)$.

The UV-Vis spectrum of $\mathrm{Il}$-DyP4 (Fig. 3a) was similar to that of Il-MnP6 (Fig. 3b). Il-DyP4 exhibited a Soret peak at $408 \mathrm{~nm}$, a $\mathrm{Q}$ band at $527 \mathrm{~nm}$, and a charge transfer (CT) band at $634 \mathrm{~nm}$, while $\mathrm{Il}$-MnP6 showed a Soret peak at $410 \mathrm{~nm}$, a $Q$ band at $533 \mathrm{~nm}$, with a narrow CT band at $632 \mathrm{~nm}$. The Reinheitszahl $\left(\mathrm{R}_{\mathrm{Z}}\right)$ values (calculated from the $\mathrm{A}_{408} / \mathrm{A}_{280}$ and $\mathrm{A}_{410} / \mathrm{A}_{280}$ absorption ratios) for Il-DyP4 and Il-MnP6 were 1.5 and 3.17, respectively.

\section{Redox properties of II-DyP4 and II-MnP6}

The midpoint redox potential of the $\mathrm{Fe}^{3+} / \mathrm{Fe}^{2+}$ couple $\left(E_{\mathrm{Fe}^{3+} / \mathrm{Fe}^{2+}}^{m^{\prime}}\right)$ at different $\mathrm{pH}$ values $(3.5,6.5$, and 8$)$ were estimated by CV for Il-DyP4 and Il-MnP6 (Table 4). IlDyP4 obtained the highest midpoint redox potential $\left(E_{\mathrm{Fe}^{3+} / \mathrm{Fe}^{2+}}^{m^{\prime}}=27 \pm 10 \mathrm{mV}\right)$ at $\mathrm{pH} \mathrm{3.5,} \mathrm{decreasing} \mathrm{to} \mathrm{a} \mathrm{lower}$ potential $\left(E_{\mathrm{Fe}^{3+}}^{m^{\prime}} / \mathrm{Fe}^{2+}=-232 \pm 10 \mathrm{mV}\right)$ at $\mathrm{pH}$ 8.0. Similarly, Il-MnP6 obtained the highest midpoint redox potential $\left(E_{\mathrm{Fe}^{3+}}^{m^{\prime}} / \mathrm{Fe}^{2+}=-75 \pm 10 \mathrm{mV}\right)$ at $\mathrm{pH} 3.5$, decreasing to a lower potential $\left(E_{\mathrm{Fe}^{3+} / \mathrm{Fe}^{2+}}^{m^{\prime}}=-168 \pm 10 \mathrm{mV}\right)$ at $\mathrm{pH} 8.0$. When the $\mathrm{pH}$ increased from 3.5 to 8.0, the midpoint redox potential of $\mathrm{Il}$-DyP4 was decreased by $259 \mathrm{mV}$, whereas that of $I l-\mathrm{MnP} 6$ decreased by $93 \mathrm{mV}$.

\section{Dye decolorization}

Dyes are colorful organic compounds that are widely used in the food, textile, drug, and paper industries, 

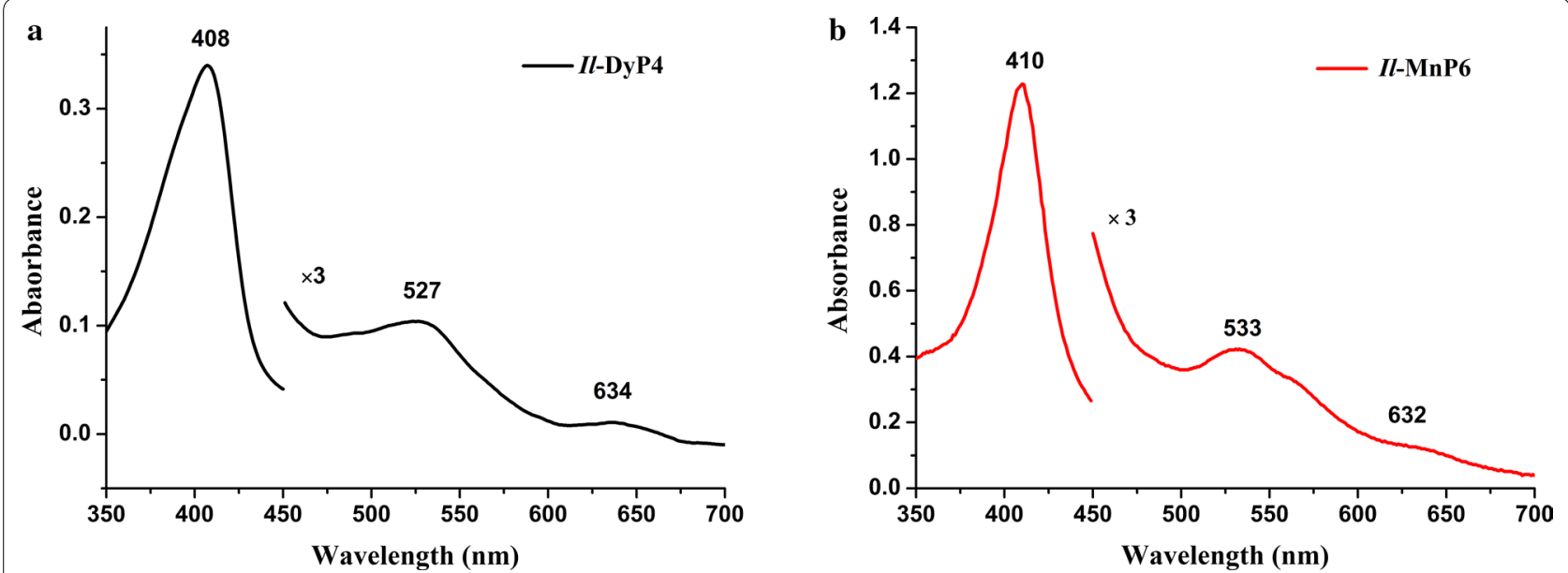

Fig. 3 a The UV-Vis absorbance spectra of II-DyP4. b The UV-Vis absorbance spectra of II-MnP6. The region between 450 and $700 \mathrm{~nm}$ has been expanded ( $\times 3$ absorbance)

Table 4 Midpoint redox potentials of II-DyP4 and II-MnP6 (vs. Ag/AgCl)

\begin{tabular}{llll}
\hline \multicolumn{5}{c}{$E_{\mathrm{Fe}^{3+} / \mathrm{Fe}^{2+}}^{\mathbf{m}^{\prime}}(\mathrm{mV})$} & \\
\hline $\mathrm{pH}$ & 3.5 & 6.5 & 8.0 \\
II-DyP4 & $27 \pm 10$ & $-87.5 \pm 10$ & $-232 \pm 10$ \\
II-MnP6 & $-75 \pm 10$ & $-100 \pm 10$ & $-168 \pm 10$ \\
\hline
\end{tabular}

often resulting in water pollution. The first DyP discovered was named because of its ability to decolorize various dyes (Kim and Shoda 1999). Accordingly, we selected 16 different dyes to examine the decolorization capability of $\mathrm{Il}$-DyP4 and $\mathrm{Il}$-MnP6 under $\mathrm{pH} 3.5,4.0$, and 4.5. The results revealed that the ability of $I l-\mathrm{DyP} 4$ to oxidize most of the anthraquinone dyes, azo dyes, phenazine dyes, triphenylmethane dyes, and aniline dyes was stronger than that of $I l-M n P 6$ (Table 5), and also greater than that of TfuDyP from Thermobifida fusca (van Bloois et al. 2010). In addition, the results revealed that $\mathrm{Il}$-DyP4 was able to decolorize anthraquinone dyes more quickly than was Il-MnP6. Interestingly, direct yellow 8 did not show any significant decolorization in our experiments. Further decolorization experiments using this dye are in progress.

In addition, we selected Poly R-478 to determine the ability of $I l$-DyP4 and $I l-M n P 6$ to degrade lignin. The maximum efficiency of $\mathrm{Il}$-DyP4 to decolorize Poly R-478 at an enzyme concentration of $100 \mathrm{nM}$ was $15.76 \%$, which was higher than the $0.66 \%$ of $I l-\mathrm{MnP} 6$ under $\mathrm{pH}$ 4.0 at $35{ }^{\circ} \mathrm{C}$ (Additional file 1: Fig. S6), indicating the $\mathrm{Il}$ DyP4 had a better ligninolytic activity compared with Il-MnP6.

When the concentration of $\mathrm{Il}$-DyP4 increased from 100 to $1000 \mathrm{nM}$, and the $\mathrm{H}_{2} \mathrm{O}_{2}$ concentration increased from
0.2 to $0.4 \mathrm{mM}$, the efficiency of $\mathrm{Il}$-DyP4 to oxidize $0.01 \%$ Poly R-478 at pH 4 increased to $24 \%$. When the concentration of $\mathrm{Il}$-DyP4 was $1000 \mathrm{nM}$, and $\mathrm{H}_{2} \mathrm{O}_{2}$ concentration increased from 0.4 to $1.2 \mathrm{mM}$, the efficiency of $\mathrm{Il}$-DyP4 to oxidize $0.01 \%$ Poly $\mathrm{R}-478$ at $\mathrm{pH} 4$ increased to $45 \%$. The maximum decolorization percentage was $50 \%$ for $\mathrm{Il}$ DyP4 for $1 \mathrm{~h}$ of reaction, and no increase in decolorization efficiency was observed $3 \mathrm{~h}$ after the initiation of the reaction.

\section{Discussion}

I. lacteus is a cosmopolitan white-rot species that has become a model ligninolytic basidiomycete. The fungus can produce LiP, MnP, and laccase simultaneously, which is similar to $P$. radiata and $T$. versicolor (Novotný et al. 2009).

Recently, we published the analysis of the genome sequence of I. lacteus F17 (Yao et al. 2017) and updated five cDNAs encoding DyPs and 13 cDNAs encoding MnPs to GeneBank. Herein, we used the available information to further analyze the amino acid sequence consensus and important residues in these DyPs and MnPs, which belong to two different heme peroxidase families. Furthermore, among these enzymes, $\mathrm{Il}$-DyP4 and the $\mathrm{Il}$ MnP6 were selected and characterized to further investigate the basis of the ligninolytic system of I. lacteus F17.

Both recombinant enzymes were expressed as inclusion bodies in $E$. coli Rosetta (DE3) and active enzymes were achieved via in vitro refolding. For optimizing of $\mathrm{Il}$ DyP4, the refolding solution needed the supplement of optimal concentrations of EDTA, hemin, and urea. Compared with $\mathrm{Il}$-DyP4, the in vitro refolding process of $\mathrm{Il}$ MnP6 was complicated and active $I l-M n P 6$ was obtained by the refolding solution containing various factors, 
Table 5 Decolorization (\%) of different kinds of synthetic dyes by II-DyP4 and II-MnP6

\begin{tabular}{|c|c|c|c|c|c|c|c|c|c|}
\hline \multirow[t]{2}{*}{ Nr. } & \multirow[t]{2}{*}{ Dye } & \multirow[t]{2}{*}{$\lambda_{\max }(\mathrm{nm})$} & \multirow[t]{2}{*}{ Concentration $(\mu \mathrm{M})$} & \multicolumn{3}{|c|}{ II-DyP4 ${ }^{\mathrm{a}}$} & \multicolumn{3}{|c|}{ II-MnP6 ${ }^{\mathrm{a}}$} \\
\hline & & & & $\mathrm{pH} 3.5$ & $\mathrm{pH} 4$ & $\mathrm{pH} 4.5$ & $\mathrm{pH} 3.5$ & $\mathrm{pH} 4$ & $\mathrm{pH} 4.5$ \\
\hline \multicolumn{10}{|c|}{ Anthraquinone dyes } \\
\hline 1 & Reactive blue 4 & 598 & 200 & 79.28 & 81.92 & 82.01 & 1.87 & 7.24 & 0.96 \\
\hline 2 & Reactive blue 5 & 600 & 100 & 74.06 & 82.73 & 83.61 & 12.40 & 18.07 & 8.26 \\
\hline 3 & Reactive blue 19 & 595 & 100 & 78.39 & 74.97 & 70.01 & 2.78 & 5.71 & 5.90 \\
\hline \multicolumn{10}{|c|}{ Azo dyes } \\
\hline 4 & Direct sky blue 5B & 598 & 100 & 80.62 & 81.45 & 77.91 & 16.95 & 59.72 & 63.75 \\
\hline 5 & Reactive black 5 & 598 & 50 & 60.57 & 59.30 & 40.86 & 0.22 & 0 & 0.69 \\
\hline 6 & Acid red 18 & 506 & 100 & 43.07 & 43.73 & 38.04 & 6.09 & 7.14 & 3.53 \\
\hline 7 & Reactive violet 5 & 570 & 100 & 92.16 & 90.81 & 80.96 & 19.97 & 21.32 & 1.10 \\
\hline 8 & Methyl orange & 464 & 50 & 33.12 & 30.21 & 29.60 & 11.21 & 9.32 & 1.95 \\
\hline 9 & Direct yellow 8 & 392 & 25 & 2.62 & 4.66 & 2.04 & 0 & 0 & 0 \\
\hline 10 & Orange G & 478 & 50 & 18.38 & 21.28 & 25.39 & 33.80 & 34.72 & 22.90 \\
\hline 11 & Orange yellow II & 484 & 50 & 28.65 & 27.94 & 36.59 & 7.58 & 4.68 & 2.18 \\
\hline 12 & Orange yellow IV & 445 & 50 & 62.55 & 60.07 & 60.16 & 13.23 & 10.40 & 4.26 \\
\hline 13 & Congo red & 498 & 10 & 0 & 38.69 & 52.77 & 0 & 0 & 0 \\
\hline \multicolumn{10}{|c|}{ Phenazine dyes } \\
\hline 14 & Neutral red & 550 & 100 & 22.50 & 24.15 & 31.09 & 0 & 2.40 & 5.68 \\
\hline \multicolumn{10}{|c|}{ Triphenylmethane dyes } \\
\hline 15 & Malachite green & 618 & 50 & 84.80 & 82.43 & 72.53 & 24.74 & 28.03 & 24.69 \\
\hline \multicolumn{10}{|c|}{ Aniline dyes } \\
\hline 16 & Basic fuchsin & 542 & 25 & 45.10 & 39.75 & 23.86 & 3.46 & 3.63 & 0.25 \\
\hline
\end{tabular}

a Percentage of dye decolorization after $30 \mathrm{~min}$ is based on the observed decrease in absorbance at $\lambda_{\max }$

including urea, hemin, GSSG, $\mathrm{CaCl}_{2}$, glycerin, $\mathrm{MnSO}_{4}$, $\mathrm{KCl}$, hemin, and $\mathrm{Ca}^{2+}$ at $\mathrm{pH}$ 8.0. Among these, a key factor of $\mathrm{Ca}^{2+}$ affected the reconstitution of this fungal MnP. These refolding differences could be ascribed to the different amino acid compositions and structures of the two proteins.

SDS-PAGE analyses indicated that purified $I l$-DyP4 was monomeric, and its molecular weight was consistent with that of reported DyPs (50-60 kDa) (Colpa et al. 2014). In addition, comparison of the $\mathrm{N}$-terminal sequence of $\mathrm{Il}$-DyP4 with that of native DyP from I. lacteus revealed their similarity. Likewise, $I l-\mathrm{MnP} 6$ purified by Ni-NTA affinity chromatography was also a monomer, and its molecular weight was almost identical to that of purified native MnP from I. lacteus F17 (Zhao et al. 2015)

In this study, the biochemical properties of the two heme peroxidases were investigated. Under acidic conditions at $\mathrm{pH} 3.5, \mathrm{Il}$-DyP4 was more robust for ABTS oxidation, which fell within the optimal $\mathrm{pH}$ range $(\mathrm{pH}$ 3-4.5) of most of the DyPs reported from fungi (Linde et al. 2014; Fernández-Fueyo et al. 2015; Behrens et al. 2016), and was similar to the optimal pH of native DyP from I. lacteus (Salvachúa et al. 2013). Intriguingly, compared with the acidic $\mathrm{pH}$ of fungi DyPs, the optimal $\mathrm{pH}$ of bacteria DyPs was 5.0-7.0 (Yu et al. 2014; Ramzi et al. 2015; Rahmanpour et al. 2016). The most distinguishing feature of DyP peroxidases is their powerful catalytic properties (Colpa et al. 2014). In the current study, IlDyP4 exhibited a broad substrate range and a strong ability to oxidize different structures of compounds.

Although all the substrates tested except VA were oxidized by the two enzymes, the kinetic constants and the catalytic efficiencies of $\mathrm{Il}$-DyP4 differed markedly from those of $\mathrm{Il}$-MnP6. Il-DyP4 was able to oxidize $\mathrm{Mn}^{2+}$ with a $k_{\text {cat }} / K_{m}$ value only an order of magnitude lower than that of the $\mathrm{Il}-\mathrm{MnP} 6$, but higher than that of Pleos-DyP1 and Pleos-DyP4 reported from P. ostreatus (FernándezFueyo et al. 2015). Remarkably, Il-DyP4 exhibited a lower $k_{\text {cat }} / K_{m}$ for VA, a nonphenolic lignin model compound, similar to that of native DyP from I. lacteus and both AjPs from Auricularia auricula-judae, showing a certain ligninolytic activity (Salvachúa et al. 2013; Linde et al. 2014). However, the VA-oxidizing activities of Il-MnP6 was not detected under our test conditions, this was different from a previous report which shows $I l \mathrm{MnP} 1$ and $I l \mathrm{MnP} 2$ from $I$. lacteus CD2 that are able to oxidize VA in the presence of $\mathrm{Mn}^{2+}$ (Qin et al. 2017). Qin et al. (2017) indicated that either malonate or oxalate buffer was essential in the VA degradation by the two MnPs. Therefore, 
the sodium tartrate buffer was changed to the malonate buffer in order to re-examine the ability of VA oxidation in Il-MnP6 from I. lacteus F17. Interestingly, the assay revealed the activity of $\mathrm{Il}-\mathrm{MnP} 6$ for VA oxidation in $50 \mathrm{mM}$ malonate buffer ( $\mathrm{pH} 3.5)$, and that the activity had improved with the increase in enzyme concentration (data not shown). Such results supports the findings from Qin et al. (2017), who showed that the $\mathrm{Mn}^{3+}$-malonate complexes may mediate oxidation of VA through the action of radicals. Yoshida and Sugano reviewed the characteristics of DyP-type peroxidases and showed that the $k_{c a t} / K_{m}$ of bacteria DyPs for anthraquinone compounds was $10^{2}-10^{5} \mathrm{~s}^{-1} \mathrm{M}^{-1}$, whereas the $k_{\text {cat }} / K_{m}$ of basidiomycota DyPs reached $10^{6}-10^{7} \mathrm{~s}^{-1} \mathrm{M}^{-1}$ (Yoshida and Sugano 2015). In the present study, the recombinant $I l$-DyP4 from I. lacteus F17 exhibited higher catalytic efficiency $\left(4.0 \times 10^{7} \mathrm{~s}^{-1} \mathrm{M}^{-1}\right)$ for RBlue 19 than did basidiomycota DyPs from I. lacteus, A. auricula-judae, and P. ostreatus (Salvachúa et al. 2013; Linde et al. 2014; Fernández-Fueyo et al. 2015). Compared with $\mathrm{Il}$-MnP6, $\mathrm{Il}$-DyP4 showed a lower affinity for azo dye RBlack 5 , although its catalytic efficiency was almost two orders of magnitude higher than that of $I l-\mathrm{MnP} 6$, and was similar to that of native $\mathrm{DyP}$ from I. lacteus and superior to that of other DyPs (Salvachúa et al. 2013). Therefore, these results revealed the remarkable ability of $\mathrm{Il}$-DyP4 to catalyze these substrates. These data also demonstrated that anthraquinone dye RBlue 19 and ABTS were the preferential substrates for Il-DyP4, which was consistent with the report by Linde et al. (2015). For Il-MnP6, $\mathrm{Mn}^{2+}$ was reconfirmed as its preferred substrate.

The effect of $\mathrm{H}_{2} \mathrm{O}_{2}$ and other compounds at different concentrations on the enzymatic activity of the two enzymes was also examined. Although, the catalytic efficiency of $\mathrm{Il}$-DyP4 for $\mathrm{H}_{2} \mathrm{O}_{2}$ was an order of magnitude higher than that of $\mathrm{Il}-\mathrm{MnP} 6$, it appeared to be more susceptible than $\mathrm{Il}$-MnP6 at lower $\mathrm{H}_{2} \mathrm{O}_{2}$ concentrations $(<7.0 \mathrm{mM})$. This could be attributed to the different amino acid residues in the heme pocket influencing the enzymatic stability. Ogola et al. (2010) increased the $\mathrm{H}_{2} \mathrm{O}_{2}$ resistibility of a DyP-type peroxidase from Anabaena sp. by the site-directed mutagenesis of methionine residues. By contrast, reducing agents, such as DTT, thiourea, and $\beta$-mercaptoethanol ( 1 and $10 \mathrm{mM})$, significantly affected the enzymatic activity of $\mathrm{Il}-\mathrm{MnP} 6$, resulting in the reduction of disulfide bonds and inactivation of the enzyme; by contrast, $I l$-DyP4 only contains a cysteine residue and lacks disulfide bonds, explaining the only small effect of this enzyme on these compounds. Interestingly, 1 and $10 \mathrm{mM}$ of $\mathrm{Fe}^{2+}$ and $\mathrm{Fe}^{3+}$ caused a dramatic decrease in activities of both enzymes, compared with other metal ions. To the best of our knowledge, the reason for this inhibition is unclear. However, it has been known that the two types of heme peroxidase share the same catalytic cycle, using $\mathrm{H}_{2} \mathrm{O}_{2}$ as an electron acceptor to form two oxidized intermediates, compound I and II, which are then reduced back to the native enzymes. In both native proteins, heme iron (protoporphyrin IX) is a penta-coordinated high-spin state $\mathrm{Fe}^{3+}$, bound to the imidazole ring $\mathrm{N}$ of the conserved proximal histidine (His), which has been proposed to be a key amino acid residue. The distance between the heme iron and proximal His influences the redox potential of ligninolytic peroxidases (Martínez 2002). In our assay, the high concentration of exogenous $\mathrm{Fe}$ ions might have disturbed and altered the formation of covalent bonds between the heme iron and His, leading to enzyme inactivation. Exogenous irons might be able to interact with the imidazole groups at a high concentration, and affect the bonding state of the active center $\mathrm{Fe}^{3+}$ of the heme porphyrin ring. Thus, more detailed studies are needed to further characterize the inhibition mechanism of Fe ions on the activity of these two enzymes. Guo et al. (2009) proposed a possible inhibition mechanism of lanthanum ions on the activity of horseradish peroxidase (HRP). They found that $\mathrm{La}^{3+}$ can combine with amide groups of the polypeptide chain and destroy the native structure of HRP. Tayefi-Nasrabadi et al. (2006) also reported conformational changes and activity alterations induced by $\mathrm{Ni}^{2+}$ ions in HRP.

Differences were observed in the CD spectra between $\mathrm{Il}$-DyP4 and $\mathrm{Il}$-MnP6, both in terms of the $\alpha$-helix and $\beta$-sheets contents, in agreement with the predicted molecular models. The UV-Vis absorption spectrum of Il-DyP4 had features similar to that of Il-MnP6. A characteristic CT band at $634 \mathrm{~nm}$ was observed in the spectrum of $\mathrm{Il}$-DyP4, indicating a high-spin heme $\mathrm{Fe}^{3+}$ state. Also, the $R_{Z}$ value was similar to that of native DyP from I. lacteus (Salvachúa et al. 2013), thus, it appears that the in vitro refolding conditions used in this study were optimized. A similar pattern was observed in Il-MnP6: a characteristic CT band at $632 \mathrm{~nm}$ was obvious, and the $R_{Z}$ value (3.17) was almost identical to that native $M n P$ from the white-rot fungus $P$. chrysosporium (Whitwam and Tien 1996). Hence, despite the tedious refolding process, $I l-\mathrm{MnP} 6$ was reconstituted successfully from inclusion bodies.

Further investigations of the midpoint redox potential of the two enzymes were carried out, and the values of $E_{\mathrm{Fe}^{3+} / \mathrm{Fe}^{2+}}^{m^{\prime}}$ indicated that $\mathrm{Il}$-DyP4 was superior to $\mathrm{Il}$ MnP6, particularly at $\mathrm{pH} 3.5$. Nevertheless, the two enzymes were differentially affected by changes in $\mathrm{pH}$. The impact of $\mathrm{pH}$ on the redox potential of $\mathrm{Il}$-DyP4 was bigger than that of $\mathrm{Il}-\mathrm{MnP6}$ (Table 4), indicating that $\mathrm{Il}$ DyP4 was more sensitive to changes in $\mathrm{pH}$. Moffeta and colleagues indicated that the redox potential of heme 
peroxidases is influenced by several factors, including the electronic nature of the amino acids ligating the heme, and the electrostatic interactions with residues surrounding the heme, as well as the solvent accessibility of the heme (Moffeta et al. 2003).

To determine the potential application ability of the two enzymes, five different structures of 16 synthetic dyes were selected and a lower enzyme concentration of $25 \mathrm{nM}$ was used to decolorize these dyes in the two same enzymatic reaction systems. The differences in decolorization percentage of 15 synthetic dyes were obvious between the two enzymes, except for Orange G. $\mathrm{Il}$-DyP4 was superior to $\mathrm{Il}-\mathrm{MnP} 6$ in all the structure types of dye tested and showed high oxidation capacities at $\mathrm{pH}$ values of 3.5-4.5, which were optimal $\mathrm{pH}$ values for most reported DyPs and MnPs (Hofrichter et al. 2010). This was suggested to be because of the increased redox potential of the oxidized heme at low $\mathrm{pH}$ (Petruccioli et al. 2009). Our voltammetric experiment data illustrated the strongest oxidization ability of $I l$-DyP4 at $\mathrm{pH} 3.5$, and showed that the redox potential declined dramatically with the increase in $\mathrm{pH}$. Thus, this result explained why DyPs required acidic $\mathrm{pH}$ conditions to complete substrate oxidization. In addition, in the case of the $\mathrm{Il}$-DyP4 system, dye decolorization was carried out directly by the addition of enzyme and $\mathrm{H}_{2} \mathrm{O}_{2}$, whereas $\mathrm{MnPs}$ catalyzed the $\mathrm{Mn}^{2+}$-mediated oxidation reaction, and an optimal concentration of $\mathrm{Mn}^{2+}$ was required for the MnP decolorization system. Thus, the biotechnological application of MnPs would be limited because of the heavy metal contamination in treated industrial wastes, whereas DyPs are only robust under acidic conditions, which would not be appropriate in some industrial applications, such as the treatment of neutral and alkaline waste in pulping and bleaching. Therefore, there is still much research to be done to enhance the industrial applicability of these enzymes.

Poly R-478, a structurally complicated and recalcitrant anthraquinone derivative, is a suitable indicator of the ability of white-rot fungi to degrade lignin, and it was used as a model compound for the measurement of ligninolytic activity (Zhao et al. 2015). The results of $I l$-DyP4 to decolorize Poly R-478 highlighted its ligninolytic activity and its ability to oxidize lignin and related recalcitrant compounds. The precise structure of $I l-\mathrm{DyP} 4$ and its key roles in lignin degradation also need to be clarified in future studies.

\section{Additional file}

Additional file 1. Additional tables and figures.

\section{Abbreviations}

DyP: dye decolorizing peroxidase; MnP: manganese peroxidase; I. lacteus F17: Irpex lacteus F17; E. coli: Escherichia coli; Rz: Reinheitszahl; $\mathrm{H}_{2} \mathrm{O}_{2}$ : hydrogen peroxide; GSSG: glutathione; DTT: dithiothreitol; DMP: 2,6-dimethoxyphenol; ABTS: 2,2'-azino-bis(3-ethylbenzothiazoline-6-sulfonic acid); VA: veratryl alcohol; PMSF: phenylmethanesulfonyl fluoride; IPTG: isopropyl- $\beta$-Dthiogalactopyranoside; RBlue 19: reactive blue 19; RBlack 5: reactive black 5; EDTA: ethylene diamine tetraacetic acid; SDS-PAGE: sodium dodecyl sulfatepolyacrylamide gel electrophoresis; PGE: pyrolytic graphite electrode; CD: circular dichroism

\section{Authors' contributions}

ZHD performed the experiments and wrote the paper. RS participated in part of the work and wrote the paper. ZHD and RS contributed equally to this work. BJL carried out the part of the MnP experiment. MWY participated in the sequence analysis of DyPs and MnPs. RJ conceived of the study, and participated in its design and helped to revise the manuscript. All authors read and approved the final manuscript.

\section{Author details}

${ }^{1}$ School of Life Science, Economic and Technology Development Zone, Anhui University, 111 Jiulong Road, Hefei 230601, Anhui, People's Republic of China. 2 Anhui Key Laboratory of Modern Biomanufacturing, Anhui University, Hefei 230601, People's Republic of China.

\section{Acknowledgements}

We thank Ping Chen for his assistance to the electrochemical experiment. We thank Yinliang Zhang for her help to structural simulation.

\section{Competing interests}

The authors declare that they have no competing interests.

\section{Availability of data and materials}

The data sets supporting the results of this manuscript are included within the article.

\section{Consent for publication}

Not applicable.

\section{Ethics approval and consent to participate}

This article does not contain any studies with human participants or animals performed by any of the authors.

\section{Funding}

This research is supported by the National Natural Science Foundation of China (31570102, 31070109).

\section{Publisher's Note}

Springer Nature remains neutral with regard to jurisdictional claims in published maps and institutional affiliations.

Received: 3 July 2018 Accepted: 10 July 2018

Published online: 17 July 2018

\section{References}

Baborová P, Möder M, Baldrian P, Cajthamlová K, Cajthaml T (2006) Purification of a new manganese peroxidase of the white-rot fungus Irpex lacteus, and degradation of polycyclic aromatic hydrocarbons by the enzyme. Res Microbiol 157:248-253

Balat M (2011) Production of bioethanol from lignocellulosic materials via the biochemical pathway: a review. Energy Convers Manage 52:858-875

Behrens CJ, Zelena K, Berger RG (2016) Comparative cold shock expression and characterization of fungal dye-decolorizing peroxidases. Appl Biochem Biotechnol 179:1404-1417

Chen WT, Zheng LL, Jia R, Wang N (2015) Cloning and expression of a new manganese peroxidase from Irpex lacteus F17 and its application in decolorization of reactive black 5. Process Biochem 50:1748-1759 
Cheng XB, Jia R, Li PS, Tu SQ, Zhu Q, Tang WZ, Li XD (2007) Purification of a new manganese peroxidase of the white-rot fungus Schizophyllum sp. F17, and decolorization of azo dyes by the enzyme. Enzyme Microb Tech 41:258-264

Cheng SN, Wilks C, Yuan ZS, Leitch M, Xu C (2012) Hydrothermal degradation of alkali lignin to bio-phenolic compounds in sub/supercritical ethanol and water-ethanol co-solvent. Polym Degrad Stabil 97:839-848

Colpa DI, Fraaije MW, van Bloois E (2014) DyP-type peroxidases: a promising and versatile class of enzymes. J Ind Microbiol Biot 41:1-7

Fernández-Fueyo E, Ruiz-Dueñas FJ, Miki Y, Martinez MJ, Hammel KE, Martinez AT (2012) Lignin-degrading peroxidases from genome of selective ligninolytic fungus Ceriporiopsis subvermispora. J Biol Chem 287:16903-16916

Fernández-Fueyo E, Ruiz-Dueñas FJ, Martínez MJ, Romero A, Hammel KE, Medrano FJ, Martínez AT (2014) Ligninolytic peroxidase genes in the oyster mushroom genome: heterologous expression, molecular structure, catalytic and stability properties, and lignin-degrading ability. Biotechnol Biofuels 7:2

Fernández-Fueyo E, Linde D, Almendral D, Lopez-Lucendo MF, Ruiz-Dueñas FJ, Martinez AT (2015) Description of the first fungal dye-decolorizing peroxidases oxidizing manganese (II). Appl Microbiol Biotechnol 99:8927-8942

Floudas D, Binder M, Riley R, Barry K, Blanchette RA, Henrissat B, Martínez AT, Otillar R, Spatafora JW, Yadav JS, Aerts A, Benoit I, Boyd A, Carlson A, Copeland A, Coutinho PM, de Vries RP, Ferreira P, Findley K, Foster B, Gaskell J, Glotzer D, Gorecki P, Heitman J, Hesse C, Hori C, Igarashi K, Jurgens JA, Kallen N, Kersten P, Kohler A, Kües U, Kumar T, Kuo A, LaButti $\mathrm{K}$, Larrondo LF, Lindquist E, Ling A, Lombard V, Lucas S, Lundell T, Martin R, McLaughlin DJ, Morgenstern I, Morin E, Murat C, Nagy LG, Nolan M, Ohm RA, Patyshakuliyeva A, Rokas A, Ruiz-Dueñas FJ, Sabat G, Salamov A, Samejima M, Schmutz J, Slot JC, John FS, Stenlid J, Sun H, Sun S, Syed K, Tsang A, Wiebenga A, Young A, Pisabarro A, Eastwood DC, Martin F, Cullen D, Grigoriev IV, Hibbett DS (2012) The Paleozoic origin of enzymatic lignin decomposition reconstructed from 31 fungal genomes. Science 336:1715-1719

Floudas D, Held BW, Riley R, Nagy LG, Koehler G, Ransdell AS, Younus H, Chow J, Chiniquy J, Lipzen A, Tritt A, Sun H, Haridas S, LaButti K, Ohmc RA, Kües U, BlanchetteRA Grigoriev IV, Minto RE, Hibbett DS (2015) Evolution of novel wood decay mechanisms in Agaricales revealed by the genome sequences of Fistulina hepatica and Cylindrobasidium torrendii. Fungal Genet Biol 76:78-92

Gasteiger E, Gattiker A, Hoogland C, Ivanyi I, Appel RD, Bairoch A (2003) ExPASy - the proteomics server for in-depth protein knowledge and analysis. Nucleic Acids Res 31:3784-3788

Guo SF, Wang LH, Lu BH, Lu TH, Ding XL, Huang XH (2009) Inhibition mechanism of lanthanum ion on the activity of horseradish peroxidase in vitro. Spectrochim Acta 75:936-940

Hofrichter M, Ullrich R, Pecyna MJ, Liers C, Lundell T (2010) New and classic families of secreted fungal heme peroxidases. Appl Microbiol Biotechnol 87:871-897

Kasinath A, Novotný Č, Svobodová K, Patel KC, Šašek V (2003) Decolorization of synthetic dyes by Irpex lacteus in liquid cultures and packed-bed bioreactor. Enzyme Microb Tech 32:167-173

Kellner H, Luis P, Pecyna MJ, Barbi F, Kapturska D, Krüger D, Zak DR, Marmeisse R, Vandenbol M, Hofrichter M (2014) Widespread occurrence of expressed fungal secretory peroxidases in forest soils. PLoS ONE 9:e95557

Kim SJ, Shoda M (1999) Purification and characterization of a novel peroxidase from Geotrichum candidum dec 1 involved in decolorization of dyes. Appl Environ Microbiol 65:1029-1035

Kinne M, Poraj-Kobielska M, Ullrich R, Nousiainen P, Sipilä J, Scheibner K, Hammel KE, Hofrichter M (2011) Oxidative cleavage of nonphenolic B-O-4 lignin model dimers by an extracellular aromatic peroxygenase. Holzforschung 65:673-679

Koo K, Foegeding PM, Swaisgood HE (1998) Isolation of RNA and DNA fragments using diatomaceous earth. Biotechnol Tech 12:549-552

Linde D, Coscolín C, Liers C, Hofrichter M, Martínez AT, Ruiz-Dueñas FJ (2014) Heterologous expression and physicochemical characterization of a fungal dye-decolorizing peroxidase from Auricularia auricula-judae. Protein Expres Purif 103:28-37

Linde D, Ruiz-Dueñas FJ, Fernández-Fueyo E, Guallar V, Hammel KE, Pogni R, Martinez AT (2015) Basidiomycete DyPs: genomic diversity, structuralfunctional aspects, reaction mechanism and environmental significance. Arch Biochem Biophys 574:66-74
Loncar N, Colpa DI, Fraaije MW (2016) Exploring the biocatalytic potential of a DyP-type peroxidase by profiling the substrate acceptance of Thermobifida fusca DyP peroxidase. Tetrahedron 72:7276-7281

Martínez AT (2002) Molecular biology and structure-function of lignindegrading heme peroxidases. Enzyme Microb Technol 30:425-444

Mendes S, Brissos V, Gabriel A, Catarino T, Turner DL, Todorovic S, Martins LO (2015) An integrated view of redox and catalytic properties of B-type PpDyP from Pseudomonas putida MET94 and its distal variants. Arch Biochem Biophys 574:99-107

Moffeta DA, Foleyb J, Hechta MH (2003) Midpoint reduction potentials and heme binding stoichiometries of de novo proteins from designed combinatorial libraries. Biophys Chem 105:231-239

Morgenstern I, Klopman S, Hibbett DS (2008) Molecular evolution and diversity of lignin degrading heme peroxidases in the agaricomycetes. J Mol Evol 66:243-257

Novotný Č, Rawal B, Bhatt M, Patel M, Šašek V, Molitoris HP (2001) Capacity of Irpex lacteus and Pleurotus ostreatus for decolorization of chemically different dyes. J Biotechnol 89:113-122

Novotný Č, Cajthaml T, Svobodova K, Šušla M, Šašek V (2009) Irpex lacteus, a white-rot fungus with biotechnological potential—review. Folia Microbiol 54:375-390

Ogola HJO, Hashimoto N, Miyabe S, Ashida H, Ishikawa T, Shibata H, Sawa Y (2010) Enhancement of hydrogen peroxide stability of a novel Anabaena sp. DyP-type peroxidase by site-directed mutagenesis of methionine residues. Appl Microbiol Biotechnol 87:1727-1736

Park J, Riaz A, Insyani R, Kim J (2018) Understanding the relationship between the structure and depolymerization behavior of lignin. Fuel 217:202-210

Petruccioli M, Frasconi M, Quaratino D, Covino S, Favero G, Mazzei F, Federic F, D'Annibale A (2009) Kinetic and redox properties of MnP II, a major manganese peroxidase isoenzyme from Panus tigrinus CBS 577.79. J Biol Inorg Chem 14:1153-1163

Qin $X$, Sun $X$ H, Huang HQ, Bai YG, Wang Y, Luo HY, Yao B, Zhang XY, Su XY (2017) Oxidation of a non-phenolic lignin model compound by two Irpex lacteus, manganese peroxidases: evidence for implication of carboxylate and radicals. Biotechnol Biofuels 10:103

Rahmanpour R, Rea D, Jamshidi S, Fulop V, Bugg TDH (2016) Structure of Thermobifida fusca DyP-type peroxidase and activity towards Kraft lignin and lignin model compounds. Arch Biochem Biophys 594:54-60

Ramzi AB, Hyeon JE, Han SO (2015) Improved catalytic activities of a dyedecolorizing peroxidase (DyP) by overexpression of ALA and heme biosynthesis genes in Escherichia coli. Process Biochem 50:1272-1276

Riley R, Salamov AA, Brown DW, Nagy LG, Floudas D, Held BW, Levasseur A, Lombard V, Morin E, Otillar R, Lindquist EA, Sun H, LaButti KM, Schmutz J, Jabbour D, Luo H, Baker SE, Pisabarro AG, Walton JD, Blanchette RA, Henrissat B, Martin F, Cullen D, Hibbett DS, Grigoriev IV (2014) Extensive sampling of basidiomycete genomes demonstrates inadequacy of the white-rot/brown-rot paradigm for wood decay fungi. Proc Natl Acad Sci USA 111:9923-9928

Ruiz-Dueñas FJ, Ludell T, Floudas D, Nagy LG, Barrasa JM, Hibbett DS, Martínez AT (2013) Lignin-degrading peroxidases in Polyporales: an evolutionary survey based on 10 sequenced genomes. Mycologia 105:1428-1444

Salvachúa D, Prieto A, Martínez ÁT, Martinez MJ (2013) Characterization of a novel dye-decolorizing peroxidase (DyP)-type enzyme from Irpex lacteus and its application in enzymatic hydrolysis of wheat straw. Appl Environ Microbiol 79:4316-4324

Sugano Y (2009) DyP-type peroxidases comprise a novel heme peroxidase family. Cell Mol Life Sci 66:1387-1403

Tayefi-Nasrabadi H, Keyhani E, Keyhani J (2006) Conformational changes and activity alterations induced by nickel ion in horseradish peroxidase. Biochime 88:1183-1197

van Bloois E, Torres Pazmiño DE, Winter RT, Fraaije MW (2010) A robust and extracellular heme-containing peroxidase from Thermobifida fusca as prototype of a bacterial peroxidase superfamily. Appl Microbiol Biot 86:1419-1430

Wang N, Ren K, Jia R, Chen WT, Sun RR (2016) Expression of a fungal manganese peroxidase in Escherichia coli: a comparison between the soluble and refolded enzymes. BMC Biotechnol 16:2-15

Whitwam R, Tien M (1996) Heterologous expression and reconstitution of fungal Mn peroxidase. Arch Biochem Biophys 333:439-446 
Yang XT, Zheng JZ, Lu YM, Jia R (2016) Degradation and detoxification of the triphenylmethane dye malachite green catalyzed by crude manganese peroxidase from Irpex lacteus F17. Environ Sci Pollut Res 23:9585-9597

Yao MW, Li WM, Duan ZH, Zhang YL, Jia R (2017) Genome sequence of the

white-rot fungus Irpex lacteus F17, a type strain of lignin degrader fungus. Stand Genomic Sci 12:55

Yoshida T, Sugano Y (2015) A structural and functional perspective of DyP-type peroxidase family. Arch Biochem Biophys 574:49-55
Yu WN, Liu WN, Huang HQ, Zheng F, Wang XY, Wu YY, Li KJ, Xie XM, Jin Y (2014) Application of a novel alkali-tolerant thermostable DyP-type peroxidase from Saccharomonospora viridis DSM 43017 in biobleaching of eucalyptus kraft pulp. PLoS ONE 9:e110319

Zhao XS, Huang XJ, Yao JT, Zhou Y, Jia R (2015) Fungal growth and manganese peroxidase production in a deep tray solid-state bioreactor, and in vitro decolorization of Poly R-478 by MnP. J Microbiol Biotechnol 25:803-813

\section{Submit your manuscript to a SpringerOpen ${ }^{\circ}$ journal and benefit from:}

- Convenient online submission

- Rigorous peer review

- Open access: articles freely available online

- High visibility within the field

- Retaining the copyright to your article

Submit your next manuscript at $\boldsymbol{\nabla}$ springeropen.com 